\title{
Harnessing Bacterial Endophytes for Promotion of Plant Growth and Biotechnological Applications: An Overview
}

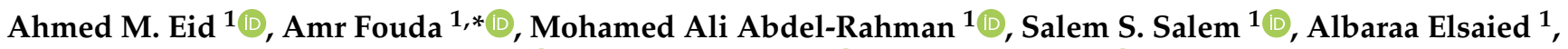 \\ Ralf Oelmüller ${ }^{2}$, Mohamed Hijri ${ }^{3,4}{ }^{-}$, Arnab Bhowmik ${ }^{5}\left(\mathbb{D}\right.$, Amr Elkelish ${ }^{2,6}{ }^{-}$and Saad El-Din Hassan ${ }^{1, *}$ \\ 1 Department of Botany and Microbiology, Faculty of Science, Al-Azhar University, Nasr City, \\ Cairo 11884, Egypt; aeidmicrobiology@azhar.edu.eg (A.M.E.); mohamedali@kyudai.jp (M.A.A.-R.); \\ salemsalahsalem@azhar.edu.eg (S.S.S.); albraa.mahmoud@azhar.edu.eg (A.E.) \\ 2 Department of Plant Physiology, Matthias Schleiden Institute of Genetics, Bioinformatics and Molecular \\ Botany, Friedrich-Schiller-University, 07743 Jena, Germany; b7oera@uni-jena.de (R.O.); \\ amr.elkelish@science.suez.edu.eg (A.E.) \\ 3 Biodiversity Centre, Institut de Recherche en Biologie Végétale, Université de Montréal and Jardin botanique \\ de Montréal, Montréal, QC 22001, Canada; mohamed.hijri@umontreal.ca \\ 4 African Genome Center, Mohammed VI Polytechnic University (UM6P), 43150 Ben Guerir, Morocco \\ 5 Department of Natural Resources and Environmental Design, North Carolina A\&T State University, \\ Greensboro, NC 27411, USA; abhowmik@ncat.edu \\ 6 Botany Department, Faculty of Science, Suez Canal University, Ismailia 41522, Egypt \\ * Correspondence: amr_fh83@azhar.edu.eg (A.F.); saad_hassan@azhar.edu.eg (S.E.-D.H.); \\ Tel.: +20-1113-351-244 (A.F.); +20-1023-884-804 (S.E.-D.H.)
}

\section{check for} updates

Citation: Eid, A.M.; Fouda, A.; Abdel-Rahman, M.A.; Salem, S.S.; Elsaied, A.; Oelmüller, R.; Hijri, M.; Bhowmik, A.; Elkelish, A.; Hassan, S.E.-D. Harnessing Bacterial Endophytes for Promotion of Plant Growth and Biotechnological Applications: An Overview. Plants 2021, 10, 935. https://doi.org/ $10.3390 /$ plants10050935

Academic Editor: Bertrand Hirel

Received: 11 April 2021

Accepted: 3 May 2021

Published: 7 May 2021

Publisher's Note: MDPI stays neutral with regard to jurisdictional claims in published maps and institutional affiliations.

Copyright: (c) 2021 by the authors. Licensee MDPI, Basel, Switzerland. This article is an open access article distributed under the terms and conditions of the Creative Commons Attribution (CC BY) license (https:// creativecommons.org/licenses/by/ $4.0 /)$.

\begin{abstract}
Endophytic bacteria colonize plants and live inside them for part of or throughout their life without causing any harm or disease to their hosts. The symbiotic relationship improves the physiology, fitness, and metabolite profile of the plants, while the plants provide food and shelter for the bacteria. The bacteria-induced alterations of the plants offer many possibilities for biotechnological, medicinal, and agricultural applications. The endophytes promote plant growth and fitness through the production of phytohormones or biofertilizers, or by alleviating abiotic and biotic stress tolerance. Strengthening of the plant immune system and suppression of disease are associated with the production of novel antibiotics, secondary metabolites, siderophores, and fertilizers such as nitrogenous or other industrially interesting chemical compounds. Endophytic bacteria can be used for phytoremediation of environmental pollutants or the control of fungal diseases by the production of lytic enzymes such as chitinases and cellulases, and their huge host range allows a broad spectrum of applications to agriculturally and pharmaceutically interesting plant species. More recently, endophytic bacteria have also been used to produce nanoparticles for medical and industrial applications. This review highlights the biotechnological possibilities for bacterial endophyte applications and proposes future goals for their application.
\end{abstract}

Keywords: biotechnological applications; endophytes; plant growth; biofertilizers; phytohormones; phytoremediation

\section{Introduction}

Endophytes are fungal and bacterial organisms that inhabit the plant endosphere without harming their hosts. They live asymptomatically in the plant cellular environment and perform symbiosis-specific functions such as synthesis of secondary metabolites or signaling molecules that function as internal and external stimuli during the mutualistic interaction [1]. Endophytic microbes are sources of novel biomolecules for the biochemical and pharmaceutical industries [2]. They produce biologically active metabolites, including immune-suppressive compounds, anticancer agents, plant growth promotors, antimicrobial volatiles, insecticides, antioxidants, and antibiotics [3,4], with huge potential for 
application in medicine, pharmaceutics industry, or agriculture (Figure 1). Moreover, endophytic microbes can improve plant growth under harsh conditions such as nutrient stress, temperature stress, salinity, trace metal stress, or drought [5]. They can also help plants to grow in contaminated environments by degrading hazardous compounds. We describe the main concepts of the application of endophytes in agriculture and biotechnology.

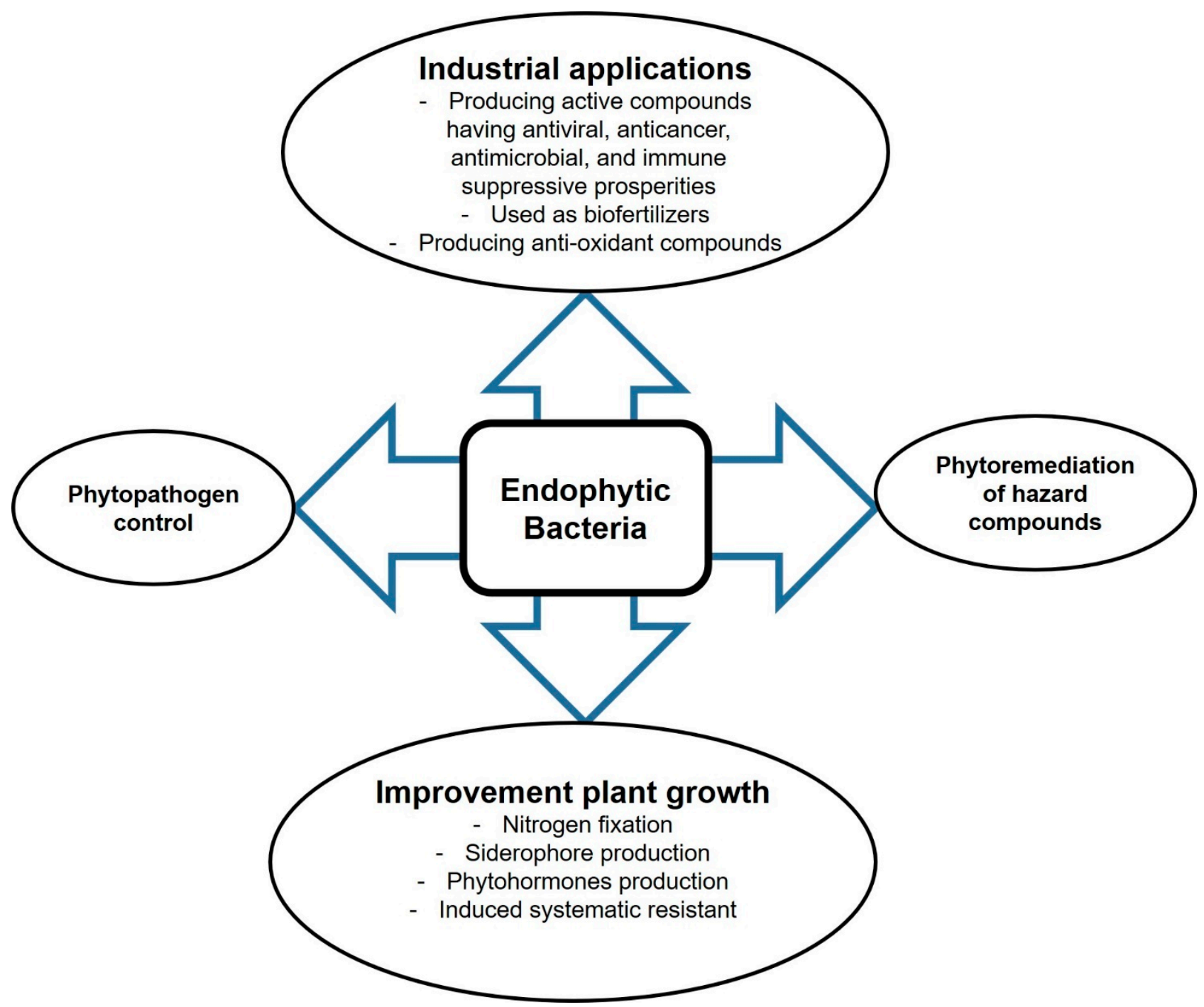

Figure 1. Prospective biotechnological applications of endophytic bacteria.

\section{Types of Bacterial Endophytes}

Taxonomically, endophytic bacteria belong to 16 phyla comprising more than 200 genera. However, the majority of them belong to the three phyla: Firmicutes, Actinobacteria, and Proteobacteria [6]. They are either Gram-negative or Gram-positive, such as Pseudomonas, Achromobacter, Agrobacterium, Xanthomonas, Acinetobacter, Microbacterium, Bacillus, and Brevibacterium [7]. Among others, mycoplasma has been isolated from the cytoplasm of marine green algae (e.g., Bryopsis hypnoides or Bryopsis pennata) [8].

Endophytic colonization can be local or systemic $[9,10]$. The plant endosphere represents a protective niche in which the endophytes are protected from biotic and abiotic stress. Moreover, endophytes can ecologically adapt to their environment and overcome plant defense responses [11].

Bacterial endophytes can also be classified as obligate or facultative endophytes. When endophytic bacteria rely on plant metabolites for survival and transfer between 
plants vertically or through the activity of different vectors, they are defined as obligate endophytes [12]. In comparison, facultative endophytes live outside the host at a definite stage of their life and are usually transmitted to plants from the surrounding atmosphere and soil [13]. The data presented in Table 1 show some examples of culturable bacterial endophytes and their attributes as plant growth-promoters.

Table 1. Some examples of recently reported culturable bacterial endophytes and their attributes as plant growth-promoters.

\begin{tabular}{|c|c|c|c|}
\hline Endophytic Bacterial Species & $\begin{array}{l}\text { Host Plant/ } \\
\text { Organ }\end{array}$ & Plant Growth Promotion Attributes & References \\
\hline Proteobacteria: Pseudomonas spp. & Nicotiana tabacum/seeds & $\begin{array}{l}\text { Siderophores, IAA, ACC deaminase } \\
\text { production, nitrogen fixation, } \\
\text { phosphorus/potassium solubilization, } \\
\text { and trace metal tolerance }\end{array}$ & [14] \\
\hline $\begin{array}{c}\text { Firmicutes: } \\
\text { Bacillus paralicheniformis }\end{array}$ & $\begin{array}{l}\text { Rice (Oryza sativa } \\
\text { L.)/ roots }\end{array}$ & Nitrogen fixation & [15] \\
\hline $\begin{array}{l}\text { Firmicutes: Bacillus mojavensis, Bacillus } \\
\text { sp. }\end{array}$ & $\begin{array}{l}\text { Ammodendron } \\
\text { bifolium/roots and } \\
\text { leaves }\end{array}$ & $\begin{array}{l}\text { IAA, ACC deaminase, amylase, } \\
\text { cellulase, protease, lipase production, } \\
\text { phosphate solubilization, } \\
\text { nitrogen fixation }\end{array}$ & [16] \\
\hline
\end{tabular}

\begin{tabular}{|c|c|c|c|}
\hline $\begin{array}{c}\text { Proteobacteria: } \\
\text { Aquabacterium, Duganella, Massilia, } \\
\text { Bordetella, Salmonella, Pantoea, Kosakonia, } \\
\text { Klebsiella, Serratia, Pseudomonas, } \\
\text { Agrobacterium, Stenotrophomonas, } \\
\text { Brevundimonas, Ancylobacter, } \\
\text { Pleomorphomonas. Actinobacterium: } \\
\text { Curtobacterium, Microbacterium, Nocardia, } \\
\text { Sediminihabitans. } \\
\text { Firmicutes: Bacillus, Micrococcus, } \\
\text { Staphylococcus, Exiguobacterium }\end{array}$ & $\begin{array}{l}\text { Sorghum bicolor/roots } \\
\text { and stems }\end{array}$ & $\begin{array}{l}\text { IAA production, fungicidal and } \\
\text { bactericidal activities, nitrogen fixation }\end{array}$ & [17] \\
\hline $\begin{array}{c}\text { Proteobacteria: Acetobacter, Burkholderia, } \\
\text { Caulobacter, Pseudomonas, Ralstonia, } \\
\text { Bradyrhizobium, Methylocapsa }\end{array}$ & $\begin{array}{l}\text { Pinus arizonica; Pinus } \\
\text { durangensis / roots, } \\
\text { phloem, and bark }\end{array}$ & $\begin{array}{l}\text { Production of active secondary } \\
\text { metabolites, metabolism of vitamins } \\
\text { and cofactors }\end{array}$ & [18] \\
\hline $\begin{array}{l}\text { Actinobacteria: } \\
\text { Streptomyces cavourensis }\end{array}$ & $\begin{array}{l}\text { Cinnamomum } \\
\text { cassia/roots }\end{array}$ & $\begin{array}{l}\text { Biosynthesis of active compounds with } \\
\text { antimicrobial and cytotoxic properties } \\
\text { and plant growth-promoting } \\
\text { capabilities. }\end{array}$ & [19] \\
\hline Proteobacteria: Sphingomonas sp. & Tephrosia apollinea/leaves & Drought tolerance & [20] \\
\hline $\begin{array}{c}\text { Actinobacteria: } \\
\text { Kocuria sp., Micrococcus luteus }\end{array}$ & $\begin{array}{c}\text { Corchorus } \\
\text { olitorius/leaves, roots, } \\
\text { seeds, and seedling }\end{array}$ & IAA and siderophore production. & [21] \\
\hline $\begin{array}{c}\text { Firmicutes: Actinobacteria } \\
\text { Proteobacteria: Curtobacterium sp., } \\
\text { Microbacterium sp., Methylobacterium sp., } \\
\text { Bacillus amyloliquefaciens }\end{array}$ & Browntop millet/seeds & $\begin{array}{c}\text { Auxin production, phosphate } \\
\text { solubilization, inhibiting fungal } \\
\text { pathogens }\end{array}$ & [22] \\
\hline $\begin{array}{l}\text { Proteobacteria: Enterobacter ludwigii, } \\
\text { Enterobacter spp., Agrobacterium } \\
\text { tumefaciens, Kosakonia cowardii, Variovorax } \\
\text { sp., Burkholderia spp., Pantoea vagans, } \\
\text { Serratia marcescens } \\
\text { Firmicutes: Bacillus sp. }\end{array}$ & $\begin{array}{l}\text { Soybean/roots, } \\
\text { stems, and leaves }\end{array}$ & $\begin{array}{l}\text { Antagonistic activity against soybean } \\
\text { pathogenic fungi and bacteria }\end{array}$ & [23] \\
\hline
\end{tabular}


Table 1. Cont.

\begin{tabular}{|c|c|c|c|}
\hline Endophytic Bacterial Species & $\begin{array}{l}\text { Host Plant/ } \\
\text { Organ }\end{array}$ & Plant Growth Promotion Attributes & References \\
\hline $\begin{array}{c}\text { Chryseobacterium endophyticum, } \\
\text { Paenibacillus castaneae, Streptomyces sp., } \\
\text { Lactobacillus plantarum, Bacillus } \\
\text { proteolyticus, Pseudomonas sp., Serratia } \\
\text { rubidaea, Klebsiella aerogenes, } \\
\text { Paraburkholderia sp., Burkholderia sp., } \\
\text { Bacillus cereus, Bacillus subtilis, } \\
\text { Enterobacter cloacae, Enterobacter sp., } \\
\text { Arthrobacter sp., Bacillus thuringiensis, } \\
\text { Bacillus sp. }\end{array}$ & $\begin{array}{l}\text { Pigeonpea/stems, roots, } \\
\text { and leaves }\end{array}$ & $\begin{array}{l}\text { Antimicrobial activity against Fusarium } \\
\text { wilt (Fusarium udum) }\end{array}$ & [24] \\
\hline Actinobacteria: Micrococcus yunnanensis & $\begin{array}{l}\text { Avicennia } \\
\text { marina/Propagule } \\
\text { teguments }\end{array}$ & $\begin{array}{l}\text { IAA, ammonium, siderophore, and } \\
\text { protease production }\end{array}$ & [25] \\
\hline $\begin{array}{c}59 \text { bacterial isolates belonging to phyla: } \\
\text { Proteobacteria, Firmicutes, and } \\
\text { Actinobacteria }\end{array}$ & $\begin{array}{l}\text { Chickpea (Cicer } \\
\text { arietinum L.)/roots }\end{array}$ & $\begin{array}{l}\text { IAA production, ammonia production, } \\
\text { cellulase production, salt tolerance }\end{array}$ & [26] \\
\hline $\begin{array}{c}\text { Firmicutes: } \\
\text { Bacillus velezensis }\end{array}$ & Peanut/seeds & Antagonistic against Sclerotium rolfsii & [27] \\
\hline $\begin{array}{l}\text { Firmicutes: } \\
\text { Bacillus subtilis }\end{array}$ & $\begin{array}{l}\text { Sugarcane/leaves and } \\
\text { stalks }\end{array}$ & $\begin{array}{l}\text { Promoting plant growth, increasing } \mathrm{N} \\
\text { and chlorophyll content }\end{array}$ & [28] \\
\hline $\begin{array}{l}\text { Proteobacteria: Delftia, Stenotrophomonas; } \\
\text { Rhizobium; Brevundimonas, Variovorax; } \\
\text { Achromobacter; Novosphingobium; } \\
\text { Comamonas; and Collimonas }\end{array}$ & $\begin{array}{l}\text { Zea mays L., Vicia faba L., } \\
\text { Secale cereale L., Triticum } \\
\text { aestivum L., Arctium } \\
\text { lappa L., and Equisetum } \\
\text { arvense L./roots and } \\
\text { stems }\end{array}$ & $\begin{array}{c}\text { IAA and siderophore production, } \\
\text { nitrogen fixation, and phosphate } \\
\text { solubilization }\end{array}$ & [29] \\
\hline $\begin{array}{l}\text { Proteobacteria: Enterobacter tabaci, } \\
\text { Pantoea agglomerans, Stenotrophomonas } \\
\text { maltophilia, Sphingomonas sanguinis, } \\
\text { Enterobacter tabaci }\end{array}$ & rice/seeds & IAA production and $\mathrm{Cd}$ tolerance & {$[30]$} \\
\hline $\begin{array}{c}\text { Actinobacteria: } \\
\text { Streptomyces niveus NRRL } 2466\end{array}$ & $\begin{array}{l}\text { Camellia spp. and related } \\
\text { genera/roots and leaves }\end{array}$ & $\begin{array}{c}\text { IAA, Ammonia, siderophores, ACC } \\
\text { deaminase, chitinase, and protease, } \\
\text { production. } \mathrm{N}_{2} \text { fixation, } \mathrm{P} \\
\text { solubilization }\end{array}$ & [31] \\
\hline $\begin{array}{c}138 \text { endophytic bacterial strains } \\
\text { belonging to the phyla Proteobacteria } \\
\text { (Pseudomonadales, Burkholderiales, and } \\
\text { Xanthomonadales) Firmicutes, and } \\
\text { Bacteroidetes (Bacillales and } \\
\text { Flavobacteriales) }\end{array}$ & $\begin{array}{l}\text { Six terrestrial orchid } \\
\text { species/roots }\end{array}$ & $\begin{array}{c}\text { Phosphate solubilization, siderophore } \\
\text { production, IAA production, } \\
\text { antagonistic activities against plant } \\
\text { pathogenic fungi }\end{array}$ & {$[32]$} \\
\hline $\begin{array}{c}\text { Herbaspirillum lusitanum (2 species), } \\
\text { Acinetobacter johnsonii (3 species), } \\
\text { Stenotrophomonas rhizophila, Agrobacterium } \\
\text { tumefaciens (4 species), Rhizobium } \\
\text { radiobacter, } \\
\text { Micrococcus yunnanensis, Paenibacillus } \\
\text { graminis, Bacillus pumilus (2 species), } \\
\text { Bacillus cereus; Bacillus muralis (2 species), } \\
\text { Terribacillus goriensis }\end{array}$ & $\begin{array}{l}\text { Cucumber/roots, shoots, } \\
\text { and leaves }\end{array}$ & $\begin{array}{l}\text { IAA production, siderophore } \\
\text { production, phosphate solubilization, } \\
\text { antibiotic production, salt tolerance }\end{array}$ & [33] \\
\hline
\end{tabular}


Table 1. Cont.

\begin{tabular}{|c|c|c|c|}
\hline Endophytic Bacterial Species & $\begin{array}{l}\text { Host Plant/ } \\
\text { Organ }\end{array}$ & Plant Growth Promotion Attributes & References \\
\hline $\begin{array}{c}\text { Bacillus cereus, Pseudomonas migulae (3 } \\
\text { species), Pseudomonas spp. (2 species), } \\
\text { Pseudomonas brassicacearum, Paenibacillus } \\
\text { lautus, Brevibacterium frigoritolerans, } \\
\text { Bacillus anthracis, Paenibacillus illinoisensis, } \\
\text { Bacillus muralis, Bacillaceae bacterium, } \\
\text { Micrococcus luteus }\end{array}$ & Sorghum/roots & $\begin{array}{l}\text { IAA production, siderophore } \\
\text { production, phosphate solubilization, } \\
\text { antibiotic production, salt tolerance }\end{array}$ & [33] \\
\hline $\begin{array}{l}\text { Bacillus safensis, Acinetobacter lwoffii, } \\
\text { Bacillus cereus (6 species), Bacillus } \\
\text { thuringiensis (4 species), Bacillus muralis (2 } \\
\text { species), Bacillus megaterium, Bacillus } \\
\text { tequilensis, Bacillus aerophilus, Bacillaceae } \\
\text { bacterium (2 species), Acinetobacter } \\
\text { johnsonii (2 species), Microbacterium } \\
\text { schleiferi, Bacillus subtilis, Paenibacillus sp., } \\
\text { Bacillus niacin, Kochuria palustris }\end{array}$ & $\begin{array}{l}\text { Tomato/roots, shoots, } \\
\text { and leaves }\end{array}$ & $\begin{array}{l}\text { IAA production, siderophore } \\
\text { production, phosphate solubilization, } \\
\text { antibiotic production, salt tolerance }\end{array}$ & [33] \\
\hline Firmicutes: Paenibacillus polymyxa & Lilium lancifolium/bulbs & $\begin{array}{l}\text { IAA, siderophore, ACC deaminase, and } \\
\text { organic acid production; nitrogen } \\
\text { fixation; phosphate solubilization; } \\
\text { antifungal activities against fungal } \\
\text { phytopathogens }\end{array}$ & [34] \\
\hline $\begin{array}{c}\text { Firmicutes and proteobacteria: } \\
\text { Actinobacteria; Bacillus, Fictibacillus, } \\
\text { Lysinibacillus, Paenibacillus, Cupriavidus, } \\
\text { and Microbacterium }\end{array}$ & $\begin{array}{l}\text { Different rice cultivars } \\
\text { such as Xiushui-48, } \\
\text { Y-003, and CO-39/roots }\end{array}$ & $\begin{array}{l}\text { Antagonistic effect against rice fungal } \\
\text { phytopathogens }\end{array}$ & [35] \\
\hline $\begin{array}{c}\text { Paenibacillus barengoltzii (2 species), } \\
\text { Bacillus amyloliquefaciens (2 species), } \\
\text { Bacillus thuringiensis (2 species), Bacillus } \\
\text { cereus (4 species) }\end{array}$ & Fagonia mollis/leaves & $\begin{array}{l}\text { Enzymatic activities, IAA production, } \\
\text { ammonia production, phosphate } \\
\text { solubilization, antibiotic activities }\end{array}$ & [36] \\
\hline Brevibacillus agri (3 species) & $\begin{array}{c}\text { Achillea } \\
\text { fragrantissima/leaves }\end{array}$ & $\begin{array}{l}\text { Enzymatic activities, IAA production, } \\
\text { ammonia production, phosphate } \\
\text { solubilization, antibiotic activities }\end{array}$ & [36] \\
\hline
\end{tabular}

\section{Plant-Bacterial Endophyte Interactions}

Interactions between bacteria and plants occur in many ways and at different levels (Figure 2). All plant organs interact with microorganisms at a specific stage of their life, and these interactions are not necessarily harmful to the plant. Plants can also benefit directly or indirectly from the interaction $[37,38]$. An example includes the well-studied rhizobialegume interaction. Many endophytic bacteria form less specific symbiotic interactions with plants, although both partners adjust their metabolisms to the symbiotic conditions and can influence the biochemical properties of the partner [39]. This can result in promotion of the growth of the plant under normal and particularly harsh conditions $[40,41]$.

Plants produce root exudates to attract beneficial bacteria, whereas bacterial endophytes recognize these compounds [42]. The bacteria in the root environment move towards the roots in response to the chemical attraction of the exudates [43]. After attachment to the root surface, they can enter the root, e.g., at lateral root emergence or openings caused by wounds or mechanical wounding [43]. Several bacterial structures are involved in their attachment to the plant surface, including fimbriae, flagella, bacterial surface polysaccharides, and lipopolysaccharides. For example, in Rhizobium spp., the surface polysaccharides are modified during the transition from free-living cells to the bacteroid form through the expression of surface antigens [44]. 


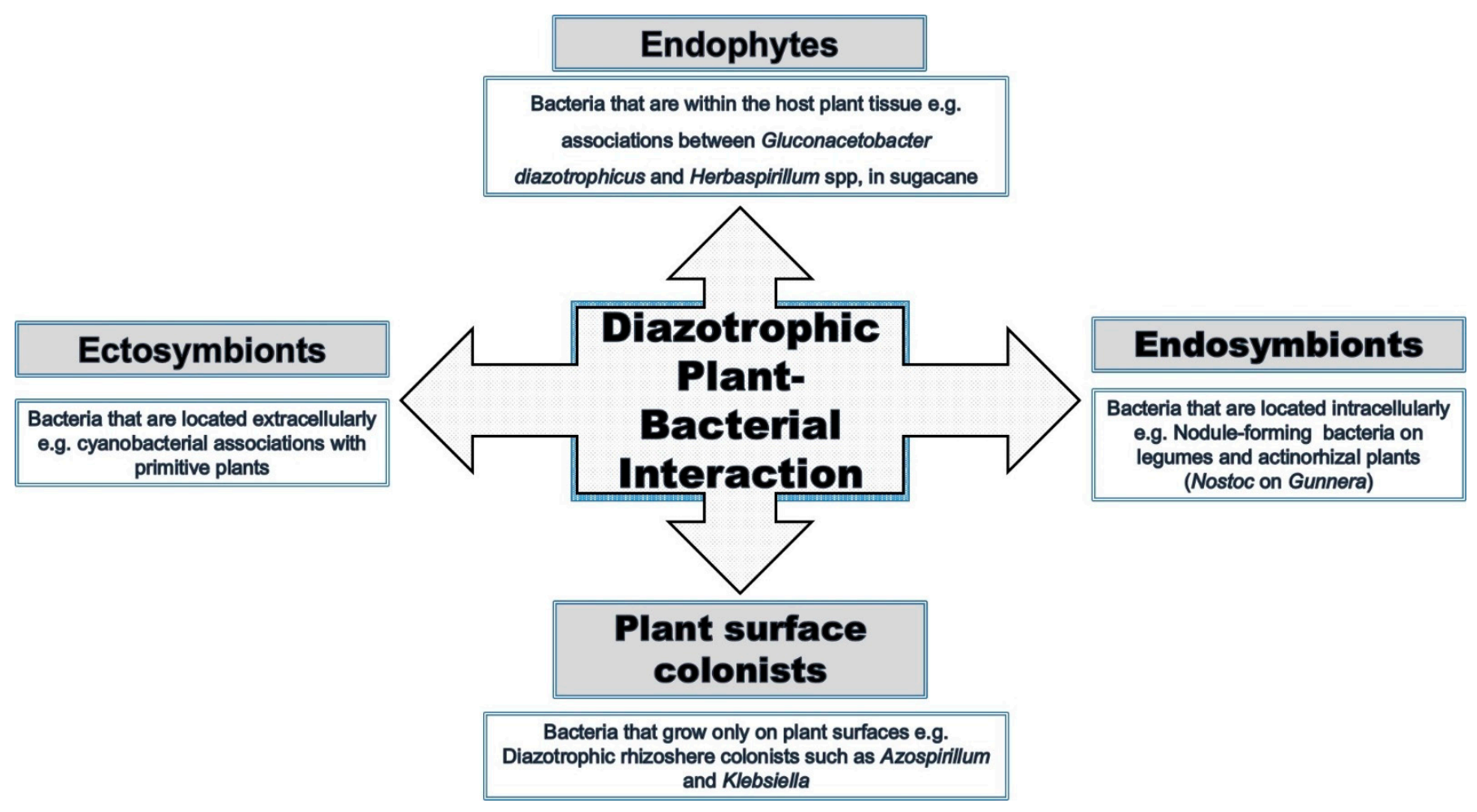

Figure 2. Endophytic plant-bacterial interactions versus other interactions.

Bacterial entrance and spread inside plant tissues require plant cell wall modification, which is achieved by the secretion of cell-wall-degrading enzymes like endoglucanases, xylanases, cellulases, and pectinases by the endophytic bacteria $[45,46]$. Penetration into the host can be active or passive. Active penetration is completed by proliferation and attachment tools involving pili, flagella, twitching motility, and lipopolysaccharides, whereas quorum sensing influences bacterial colonization and movement in the host plant [47]. Passive penetration occurs through cracks on root tips or root emergence zones or arising from the activities of harmful organisms [12].

Bacterial colonization often begins at the root surface. After successful entry, the bacteria can move to aerial parts by the transpiration stream and with the support of the bacterial flagella [48]. This colonization pattern begins with intracellular microbial access through root hairs [49]. Endophytes can pass through the plant cell wall and enter the root cell either directly by the secretion of plant cell-wall-degrading enzymes and passage through the plant plasma membrane or by rhizophagy. Rhizophagy is a phenomenon in which many plants get microbes from the soil into their cells and digest them as a source of essential nutrients [50,51].

However, most endophytes reside in the intercellular spaces of their hosts, i.e., in sites that are rich in carbohydrates, inorganic nutrients, and amino acids [52]. Besides root colonization, endophytic bacteria can also occupy the intercellular spaces of stems, leaves, seeds, flowers, fruits, and xylem vessels [53-57]. Endophytes with intracellular colonization are difficult to study because they are often non-cultivable [58].

\section{Applications of Bacterial Endophytes}

\subsection{Agricultural Applications}

\subsubsection{Plant Growth Promotion}

Endophytic bacteria utilize the same mechanisms as rhizosphere bacteria for enhancing plant growth in silviculture, horticulture, and agriculture, as well as in phytoremediation [59]. The growth-promoting effect can be either direct or indirect (Figure 3). 


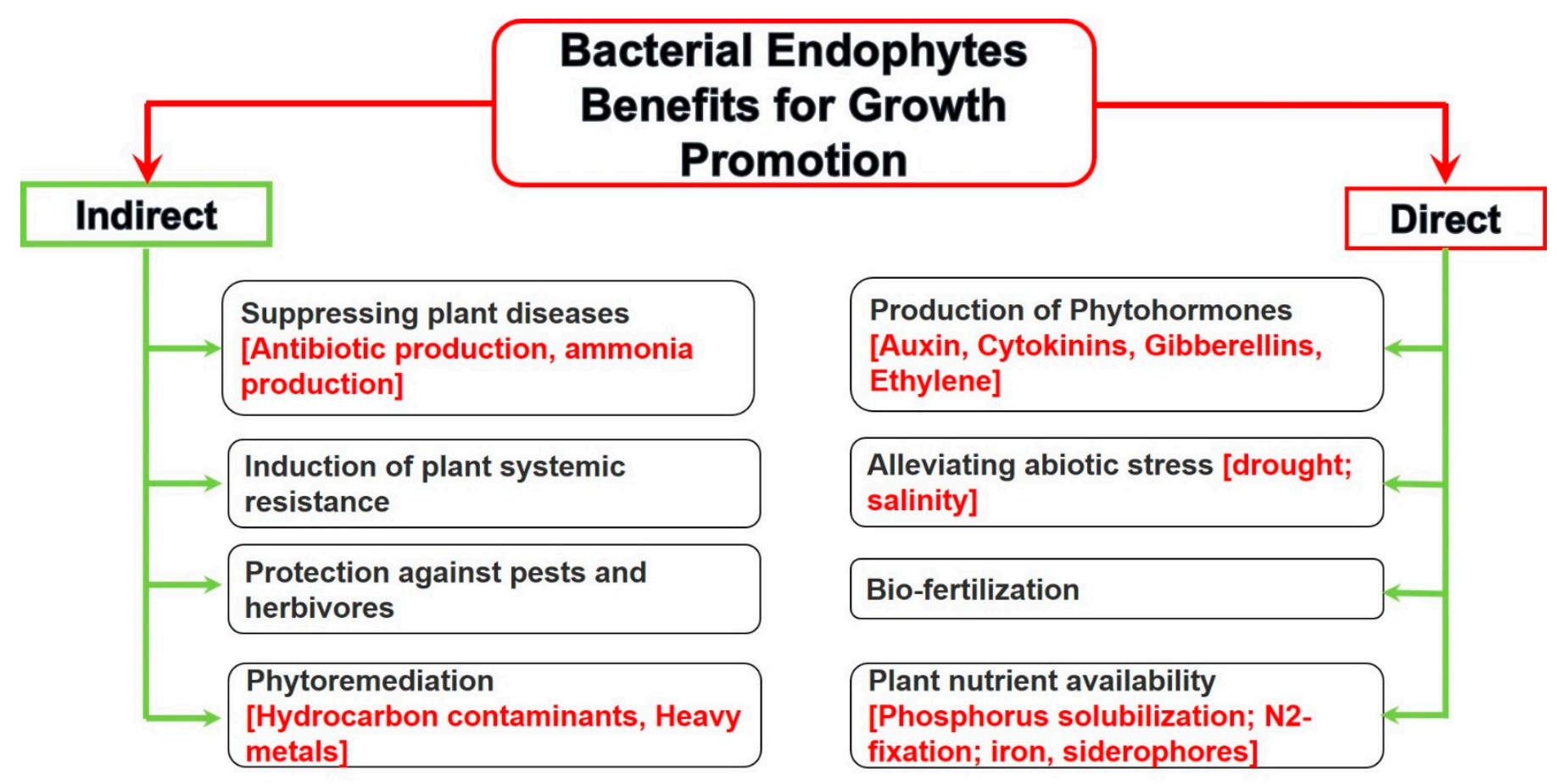

Figure 3. Direct and indirect growth-promoting attributes by endophytic bacteria.

Direct Plant Growth Promotion

A. Phytohormone production

Plant growth regulators or phytohormones are organic substances that modify, inhibit, or promote plant growth and development at low concentrations $(<1 \mathrm{mM})$ [60]. For agricultural applications, they are either chemically synthesized, extracted from plant materials, or produced by microbial fermentation. However, their complex chemical structures or low abundance in plants often prevent the application of these techniques [61]. Alternatively, the development of techniques for fermentative hormone production may decrease the production costs and increase productivity.

The main phytohormones produced by endophytic bacteria are auxins, cytokinins, abscisic acid, ethylene, brassinosteroids, gibberellins, strigolactones, and jasmonates [59,62-64].

Indole-3-acetic acid (IAA) primarily promotes plant cell elongation and differentiation [65]. In symbiosis, the IAA produced by the bacteria stimulates adventitious and lateral root development, promotes nutrient access, and enhances root exudation to increase the interaction [66,67]. Common endophytic IAA producers belong to the bacterial genera Azospirillum, Azotobacter, Alcaligenes, Herbaspirillum, Enterobacter, Pseudomonas, Klebsiella, Rhizobium, Burkholderia, Pantoea, Bacillus, Acetobacter, and Rhodococcus [68-71]. They are often found in nature, as recently shown for medicinal plant populations in Egypt [36,72].

The plant defense hormone ethylene is involved in various stress responses, as well as developmental processes, including root development. In the rhizobia-legume symbiosis, it participates in the nodulation process [73]. Bacterial endophytes can possess a 1aminocyclopropane-1-carboxylate deaminase (ACC deaminase), which generates the nitrogen sources ammonia and $\alpha$-ketobutyrate from the ethylene precursor ACC [74]. Therefore, these bacterial endophytes can promote plant growth under nitrogen-limitation conditions through the secretion of ACC deaminases. This also results in a stronger immune system and promotes tolerance against abiotic stress. For instance, Pseudomonas brassicacearum SVB6R1 increases salt stress tolerance in sorghum plants through the section of ACC deaminase [33]. Moreover, Paenibacillus polymyxa from the bulbs of Lilium lancifolium promotes the growth of two Lilium varieties through secretion of ACC deaminase, among other effects [34]. 
Several studies reported endophytic bacterial species which produce gibberellins and cytokinins. Gibberellins control plant growth and development through enhanced seed germination, stem and leaf growth promotion, stimulation of flowering and fruit development, and delaying plant aging [75,76]. Cytokinin controls cell division and differentiation, increases resistance to biotic and abiotic stress, enhances phloem transport, and promotes flowering and axillary bud growth [77]. The endophytic Azospirillum lipoferum was inoculated in a maize plant previously treated by gibberellin inhibitor synthesis and subjected to drought stress. The inoculated maize plant performed better than the uninoculated controls, particularly under stress due to the bacterial gibberellin [78]. Moreover, endophytic bacterial strains including Pseudomonas resinovorans and Paenibacillus polymaxa isolated from Gynura procumbens exhibited an efficient ability to produce compounds similar to cytokinin in a broth extract [79]. These examples of endophytic bacteria-mediated biosynthesis of different phytohormones are illustrated in Table 2.

Table 2. Some examples of endophytic bacterial strain-mediated biosynthesis of phytohormones.

\begin{tabular}{|c|c|c|c|c|}
\hline Hormone & Producer Strain & Plant Source & Function/Effect & Reference \\
\hline Gibberellins & $\begin{array}{c}\text { Bacillus amyloliquefaciens } \\
\text { strain RWL-1 }\end{array}$ & $\begin{array}{l}\text { Oryza sativa L. } \\
\text { (Poales: Poaceae) }\end{array}$ & $\begin{array}{l}\text { Plant growth promotion, } \\
\text { hormone regulation }\end{array}$ & {$[62]$} \\
\hline Abscisic acid & Azospirillum lipoferum & Maize & $\begin{array}{l}\text { Alleviating drought stress } \\
\text { symptoms in maize }\end{array}$ & [78] \\
\hline Cytokinin's & Bacillus subtilis & lettuce plants & $\begin{array}{l}\text { Increased plant shoot and } \\
\text { root weight by } \\
\text { approximately } 30 \%\end{array}$ & [80] \\
\hline $\begin{array}{l}\text { Auxin (indol } \\
\text { acetic acid) }\end{array}$ & $\begin{array}{l}\text { B. amyloliquefaciens B. cereus } \\
\text { and Bacillus subtilis }\end{array}$ & $\begin{array}{l}\text { Capsicum annuum } \\
\text { L. (Solanales: } \\
\text { Solanaceae) }\end{array}$ & $\begin{array}{l}\text { Anthracnose control, plant } \\
\text { growth promotion, and } \\
\text { biomass improvement }\end{array}$ & {$[81,82]$} \\
\hline Auxins & $\begin{array}{l}\text { B. amyloliquefaciens strain B14 } \\
\text { and Bacillus sp. strains B19 } \\
\text { and P12 }\end{array}$ & Phaseolus vulgaris & $\begin{array}{l}\text { Plant growth promotion, } \\
\text { seed germination }\end{array}$ & [83] \\
\hline Indol acetic acid & $\begin{array}{l}\text { B. subtilis strain } \\
\text { NA-108 }\end{array}$ & $\begin{array}{l}\text { Fragaria ananassa } \\
\text { Duchesne (Rosales: } \\
\text { Rosaceae) }\end{array}$ & $\begin{array}{l}\text { Plant growth promotion and } \\
\text { biomass improvement }\end{array}$ & [84] \\
\hline IAA & $\begin{array}{l}\text { Pseudomonas aeruginosa. } \\
\text { Bradyrhizobium sp. }\end{array}$ & Soybean & Plant growth-promoting & [85] \\
\hline $\begin{array}{l}\text { IAA, gibberellins, } \\
\text { and cytokinin }\end{array}$ & $\begin{array}{c}\text { Acitenobacter braumalli, } \\
\text { Enterobacter asburiae, } \\
\text { Pseudomonas aeruginosa, } \\
\text { Pseudomonas fulva, } \\
\text { Pseudomonas lini; } \\
\text { Pseudomonas montelli, } \\
\text { Pseudomonas putida, } \\
\text { Pseudomonas thivervalensis, } \\
\text { Sinorhizobium meliloti, } \\
\text { Klebsiella pneumoniae }\end{array}$ & Maize & $\begin{array}{l}\text { Plant growth-promoting, } \\
\text { alleviating drought stress, } \\
\text { biocontrol activity }\end{array}$ & [86] \\
\hline IAA & Acinetobacter guillouiae & Wheat & Plant growth-promoting; & [87] \\
\hline IAA & Arthrobacter sulfonivorans & Wheat & Plant growth-promoting & [88] \\
\hline IAA & $\begin{array}{c}\text { Acinetobacter calcoaceticus, } \\
\text { Bacillus amyloliquefaciens, } \\
\text { Enterobacter cloaca, } \\
\text { Pseudomonas putida }\end{array}$ & Soybean & & [89] \\
\hline
\end{tabular}




\section{B. Biofertilization}

\section{a. Nitrogen fixation}

Manufacturing nitrogenous fertilizers is costly, and their usage increases the pollution of groundwater with nitrate [90]. Interestingly, biological nitrogen fixation (BNF) accounts for about two-thirds of the globally fixed nitrogen [91]. Apart from photosynthesis, biological nitrogen fixation (BNF) is the most remarkable biological process, and this process is limited to prokaryotic organisms only. Bacterial endophytes can establish closed relations with certain crops. The plant endosphere contains excess carbon and a lack of oxygen, which presents suitable conditions for nitrogen fixation that can be then transported by endophytes to their host plant. Interestingly, endophytic bacteria can fix nitrogen within plants without forming nodule-like structures [92]. Some endophytic bacteria possess BNF genes that enable them to convert nitrogen gas $\left(\mathrm{N}_{2}\right)$ to other nitrogen forms such as nitrate and ammonium, which can be utilized by host plants [93,94]. In Brazil, it was observed that sugarcane plant (Saccharum officinarum L) cultivated without nitrogen fertilizers and infected with diazotrophic endophytes such as Herbaspirillum seropedicae and Acetobacter diazotrophicus were able to derive all their nitrogenous needs from atmospheric $\mathrm{N}_{2}$ [95] Regarding nitrogen fixation, endophytes do better than rhizosphere microbes in promoting plant growth and health, and help the plant thrive in nitrogen-restricted soil [96].

Bacterial endophyte inoculation has contributed to increased biomass over un-inoculated control plants, as noted by several authors (Table 3). Some endophytic strains of Enterobacter spp. and Klebsiella spp. have been reported to fix $\mathrm{N}_{2}$ and promote the growth of sugarcane under gnotobiotic and natural conditions [97-100]. Wei et al. [101] isolated Klebsiella variicola DX120E, a nitrogen-fixing bacterium, from the roots of the ROC22 sugarcane cultivar. This strain was capable of fixing $\mathrm{N}_{2}$ in association with sugarcane plants under gnotobiotic conditions, promoting GT21 cultivar growth and plant uptake of N, P, and K under greenhouse conditions. The total nitrogen content of Poa pratensis L. plants was increased by $37 \%$ after inoculation with the endophytic Burkholderia vietnamiensis WPB strain [102]. Significant increases in root and shoot biomass and flowers/fruits were obtained by the inoculation of cherry tomato Lycopersicon lycopericum cv 'Glacier', with Rahnella strain WP5, while an approximately twofold increase in total nitrogen content in root tissue of Lolium perenne was reported when the plant was inoculated with a multi-strain endophytic consortium (PTD1, WPB, WP19, WP1, and WW6) [103]. Andrade et al. [104] reported that about 40 endophytic bacterial strains were isolated from banana roots (Musa L.); out of these, 20 endophytic isolates had the capacity to grow in N-free media. Out of 20 isolates, four endophytic strains belonging to the Firmicutes (Bacillus spp.) showed the ability to fix nitrogen when assessed by the Kjeldahl and acetylene reduction assay methods. Moreover, these four isolates exhibit banana growth-promoting activities in vivo through nitrogen fixation, IAA production, and phosphate solubilization. The diazotrophic endophytic bacteria and their nitrogen-fixing capacity for plant growth promotion are summarized in Table 3.

\section{b. Phosphate Solubilization}

Plants take up monobasic $\left(\mathrm{H}_{2} \mathrm{PO}_{4}{ }^{-}\right)$and dibasic phosphate $\left(\mathrm{HPO}_{4}{ }^{2-}\right)$ from the soil, whereas $95-99 \%$ of soil phosphorus is non-available for plants because it is present in precipitated, immobilized, and insoluble forms [119]. In agriculture, phosphate deficiency is compensated by applying chemical or organic phosphate fertilizers [120].

Endophytes increase phosphorus availability for plants, as they dissolve insoluble phosphate via secretion of organic acids, chelation, and/or ion exchange [121]. Furthermore, endophytes can secrete P-solubilizing enzymes, such as phosphatase, phytase, and C-P lyase (Figure 4) [122]. Secretion of organic acids such as citric, malonic, fumaric, tartaric, gluconic, acetic, or glycolic acid is considered the main mechanism involved in P solubilization. The P-solubilizing activity of the bacteria is usually correlated with a decrease in the $\mathrm{pH}$ value of the medium, which varies due to bacterial species (Figure 4). For example, the phosphate-solubilizing Bacillus spp. secretes itaconic, lactic, isobutyric, isovaleric, and acetic acid, and thus acidifies the medium and rhizosphere during sym- 
biosis [123]. Other P-solubilizing mechanisms are the secretion of exopolysaccharides (Figure 4). [124] and the degradation of P-containing substances.

Table 3. Recent studies describing the diazotrophic endophytic bacteria, and their isolation and inoculation in agricultural plants.

\begin{tabular}{|c|c|c|c|c|}
\hline $\begin{array}{c}\text { Diazotrophic Endophytic } \\
\text { Bacteria }\end{array}$ & Plant Source & Inoculated in & $\begin{array}{l}\text { Capacity of N-Fixing } \\
\text { Confirmed by }\end{array}$ & Reference \\
\hline $\begin{array}{c}\text { Proteobacteria: (Acinetobacter } \\
\text { calcoaceticus, Enterobacter cloacae, } \\
\text { Pseudomonas putida). } \\
\text { Firmicutes: (Bacillus cereus, } \\
\text { Bacillus amyloliquefaciens) }\end{array}$ & Glycine $\max \mathrm{L}$. & In vitro assay & $\begin{array}{l}\text { - Growth on Ashby's N-free } \\
\text { medium, } \\
\text { nifH gene amplification }\end{array}$ & [89] \\
\hline $\begin{array}{l}\text { Firmicutes: (Bacillus subtilis } \\
\text { EB-04, Bacillus pumilus EB-64, } \\
\text { Bacillus pumilus EB-169, } \\
\text { Paenibacillus sp. EB-144) }\end{array}$ & Banana tree & In vitro assay & $\begin{array}{l}\text { - } \\
\text { - } \\
\quad \text { nif } \mathrm{H} \text { gene amplification }\end{array}$ & [104] \\
\hline $\begin{array}{l}\text { Actinobacteria (Arthrobacter), } \\
\text { Proteobacteria (Rhizobium), } \\
\text { Firmicutes (Bacillus spp.) }\end{array}$ & $\begin{array}{l}\text { Diverse Poaceae family } \\
\text { plants (maize, wheat, } \\
\text { pearl millet, sorghum, } \\
\text { and rice) }\end{array}$ & Wheat & - $\quad$ Kjeldahl method & [105] \\
\hline $\begin{array}{c}\text { Proteobacteria (Pseudomonas } \\
\text { aeruginosa PM389) }\end{array}$ & Pennisetum glaucum & Wheat & $\begin{array}{l}\text { - } \quad \text { Acetylene reduction assay } \\
\text { - } \quad \text { nif } \mathrm{H} \text { gene detection }\end{array}$ & [106] \\
\hline $\begin{array}{c}\text { Proteobacteria } \\
\text { (Herbaspirillum sp.) }\end{array}$ & $\begin{array}{c}\text { Tea plants (Camellia } \\
\text { sinensis var. assamic and } \\
\text { C. sinensis) }\end{array}$ & In vitro assay & $\begin{array}{l}\text { - } \quad \text { Acetylene reduction assay } \\
\text { - } \quad \text { nif } \mathrm{H} \text { gene detection }\end{array}$ & [107] \\
\hline $\begin{array}{l}\text { Proteobacteria } \\
\text { (Burkholderia spp., Klebsiella spp., } \\
\text { Novosphingobium spp., } \\
\text { Sphingomonas spp.) }\end{array}$ & Rice (Oryza sativa) & Rice (Oryza sativa) & - Acetylene reduction assay & [108] \\
\hline $\begin{array}{c}\text { Proteobacteria (Pseudomonas } \\
\text { spp., Caballeronia sordidicola, } \\
\text { Rhizobium herbae) } \\
\text { Actinobacteria (Rathayibacter } \\
\text { tanaceti, Frigoribacterium } \\
\text { endophyticum, Herbiconiux solani) } \\
\text { Bacteroidetes (Flavobacterium } \\
\text { aquidurense) }\end{array}$ & $\begin{array}{l}\text { Lodgepole pine (Pinus } \\
\text { contorta var. latifolia) }\end{array}$ & $\begin{array}{l}\text { In vitro assay; } \\
\text { lodgepole pine } \\
\text { (Pinus contorta) }\end{array}$ & $\begin{array}{ll}\text { - } & \text { Acetylene reduction } \\
\text { activity } \\
\text { - } & \text { Amplification of nif } \mathrm{H} \text { gene } \\
\text { - } & { }^{15} \mathrm{~N} \text { isotope dilution assay }\end{array}$ & [109] \\
\hline $\begin{array}{c}\text { Firmicutes (Paenibacillus } \\
\text { kribbensis HS-R01, Paenibacillus } \\
\text { kribbensis HS-R14) }\end{array}$ & $\begin{array}{l}\text { Rice (Oryza sativa var. } \\
\text { japonica) }\end{array}$ & $\begin{array}{l}\text { Rice (Oryza sativa } \\
\text { var. japonica) }\end{array}$ & - $\quad$ nif $\mathrm{H}$ gene amplification & [110] \\
\hline $\begin{array}{c}\text { Firmicutes (Bacillus spp.) } \\
\text { Proteobacteria (Enterobacter sp.) }\end{array}$ & Zea mays L. & Zea mays $\mathrm{L}$. & $\begin{array}{l}\text { - } \quad \text { Acetylene reduction assay } \\
\text { - } \quad \text { nif } \mathrm{H} \text { gene amplification }\end{array}$ & [111] \\
\hline $\begin{array}{l}\text { Firmicutes (Paenibacillus } \\
\text { polymyxa } \mathrm{P} 2 \mathrm{~b}-2 \mathrm{R})\end{array}$ & $\begin{array}{l}\text { Lodgepole pine } \\
\text { (Pinus contorta var. } \\
\text { latifolia) }\end{array}$ & Zea mays $\mathrm{L}$. & $\begin{array}{ll}\text { - } & \text { Acetylene reduction assay } \\
\text { - } & \text { nif } \mathrm{H} \text { gene amplification } \\
\text { - } & { }^{15} \mathrm{~N} \text { isotope dilution assay }\end{array}$ & [112] \\
\hline $\begin{array}{l}\text { Firmicutes (Paenibacillus } \\
\text { polymyxa } \mathrm{P} 2 \mathrm{~b}-2 \mathrm{R})\end{array}$ & $\begin{array}{l}\text { Lodgepole pine } \\
\text { (Pinus contorta var. } \\
\text { latifolia) }\end{array}$ & $\begin{array}{l}\text { Canola (Brassica } \\
\text { napus L.) and } \\
\text { tomato (Solanum } \\
\text { lycopersicum) }\end{array}$ & $\begin{array}{ll}\text { - } & \text { Acetylene reduction assay } \\
\text { - } & \text { nif } \mathrm{H} \text { gene amplification } \\
\text { - } & { }^{15} \mathrm{~N} \text { isotope dilution assay }\end{array}$ & [113] \\
\hline
\end{tabular}


Table 3. Cont.

\begin{tabular}{|c|c|c|c|c|}
\hline $\begin{array}{c}\text { Diazotrophic Endophytic } \\
\text { Bacteria }\end{array}$ & Plant Source & Inoculated in & $\begin{array}{l}\text { Capacity of N-Fixing } \\
\text { Confirmed by }\end{array}$ & Reference \\
\hline $\begin{array}{c}\text { Firmicutes: (Bacillus spp, } \\
\text { Paenibacillus spp.) } \\
\text { Proteobacteria: (Caballeronia } \\
\text { spp., Pseudomonas spp.) }\end{array}$ & Spruce tree & In vitro assay & - $\quad$ Acetylene reduction assay & [114] \\
\hline $\begin{array}{c}\text { Proteobacteria: (Burkholderia, } \\
\text { Sphingomonas, Bradyrhizobium sp., } \\
\text { Azospirillum brasilens, } \\
\text { Rhodospirillum rubrum, } \\
\text { Rhodobacter capsulatus) } \\
\text { Cyanobacteria: (Nostoc } \\
\text { punctiforme) } \\
\text { Euryarchaeota: (Methanococcus } \\
\text { maripaludis, Methanosarcina } \\
\text { acetivoran) }\end{array}$ & Populus trichocarpa & In vitro assay & $\begin{array}{ll}\text { - } & { }^{15} \mathrm{~N}_{2} \text { assay } \\
\text { - } & \text { Acetylene reduction assay } \\
\text { - } & \text { nif } \mathrm{H} \text { gene amplification }\end{array}$ & [115] \\
\hline $\begin{array}{c}\text { Proteobacteria: (Azospirillum } \\
\text { amazonense AR3122, Burkholderia } \\
\text { vietnamiensis AR1122) }\end{array}$ & Rice (Oryza sativa $\mathrm{L}$ ) & $\begin{array}{l}\text { Rice (Oryza sativa } \\
\text { L.) }\end{array}$ & - $\quad$ Acetylene reduction assay & [116] \\
\hline $\begin{array}{c}\text { Proteobacteria: } \\
\text { (Gluconacetobacter diazotrophicus, } \\
\text { Azospirillum, Herbaspirillum } \\
\text { seropedicae, Herbaspirillum } \\
\text { rubrisubalbicans, Burkholderia } \\
\text { tropica) }\end{array}$ & Sugarcane & Sugarcane & $\begin{array}{ll}\text { - } & \text { Kjeldahl method. } \\
\text { - } & \text { Abundance of }{ }^{15} \mathrm{~N} \text { in leaves } \\
\text { - } & \text { Isotopic }{ }^{15} \mathrm{~N} \text { dilution assay }\end{array}$ & [117] \\
\hline $\begin{array}{c}\text { Proteobacteria: (Pseudomonas } \\
\text { spp., Rhizobium spp., } \\
\text { Duganella spp.) }\end{array}$ & Ageratina adenophora & In vitro assay & $\begin{array}{l}\text { Growth on nitrogen-free } \\
\text { liquid medium }\end{array}$ & [118] \\
\hline
\end{tabular}

Although it is not clear how bacteria living in a plant can dissolve the insoluble phosphate that is located outside of the plant, $50 \%$ of the endophytes isolated from ginseng were able to dissolve phosphate [125]. Comparably high numbers of endophytes isolated from soybean, cactus, legumes, strawberry, and sunflower were effective phosphate solubilizers [126-128]. Very high phosphate-solubilizing activity was recorded for the Bacillus species of B. megaterium and B. amyloliquefasciens, which solubilized insoluble zinc and potassium salts [129].

The utilization of endophytic bacteria inoculants as microbial biofertilizer candidates would provide a promising alternative to chemical fertilizers and for commercial applications. Inoculation of peanut (Arachis hypogaea L.) with the P-solubilizing nodule endophyte Pantoea J49 increased the aerial dry weight in greenhouse experiments [130]. Pseudomonas letiola mobilized insoluble P and increased the shoot length and growth of the apple tree variety Ligol [131]. Moreover, inoculation of Rhodococcus sp. EC35, Pseudomonas sp. EAV, and Arthrobacter nicotinovorans EAPAA enhanced the Pavailability and plant growth of Zea mays in soils amended with tricalcium phosphate [132]. Oteino et al. [133] found that the endophytic Pseudomonas strains L111, L228, and L321 isolated from the leaves of Miscanthus giganteus showed high P solubilization activity. Pseudomonas fluorescens L321 inoculation resulted in gluconic acid accumulation in the medium and consequently larger $P$. sativum L. plants. Joe et al. [134] investigated the effect of two salt-tolerant and phosphate-solubilizing bacteria (Acinetobacter sp. and Bacillus sp.) on Phyllanthus amarus and showed that the endophytes were responsible for the better performance and faster growth of the plants due to the promotion of germination, better $\mathrm{P}$ uptake, and stimulation of the immune system by promoting the biosynthesis of phenolic compounds, the radical scavenging system, and antioxidative enzymes. 


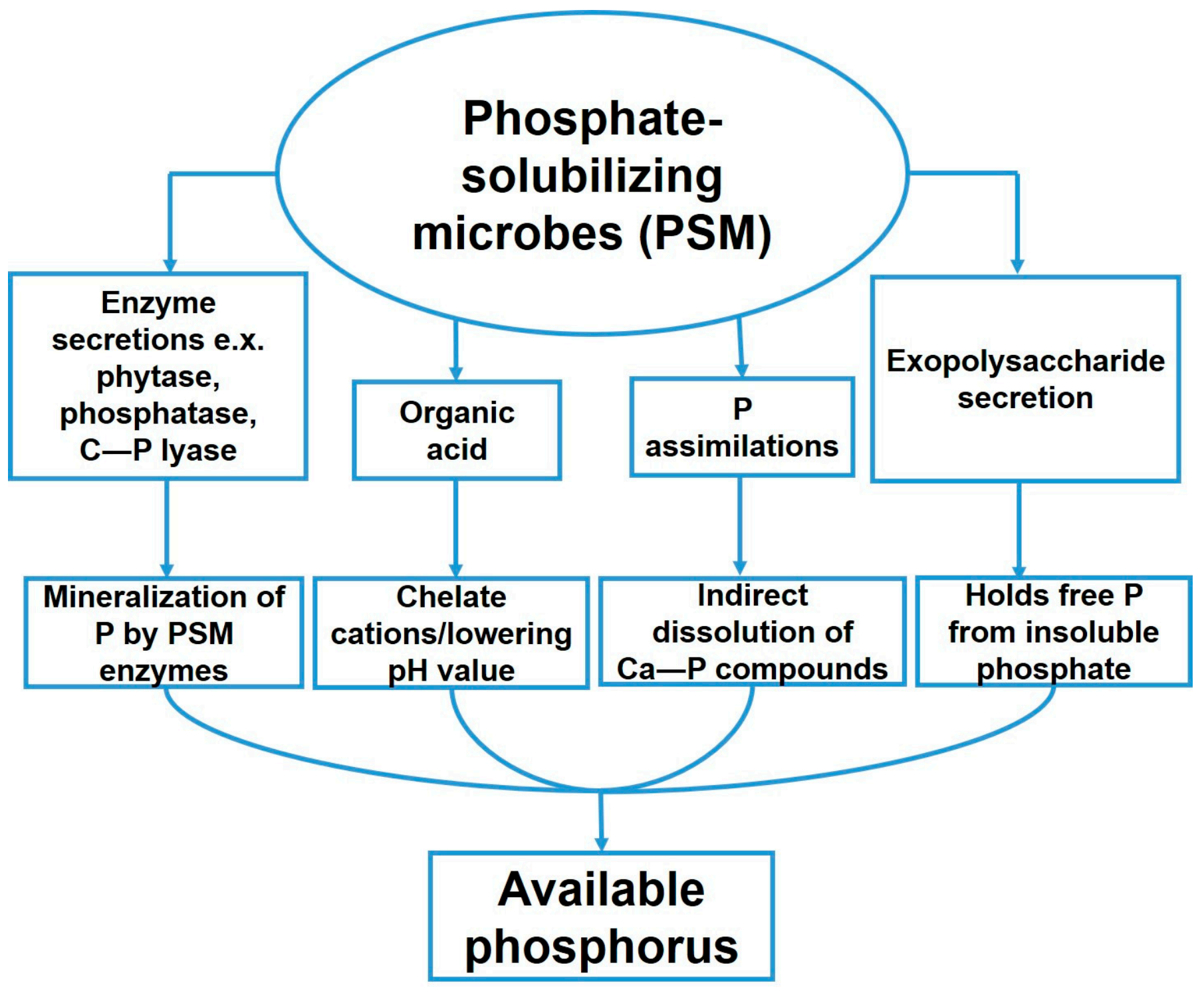

Figure 4. Different mechanisms utilized by phosphate-solubilizing microbes to solubilize phosphate.

Chen et al. [135] showed that the endophytic Pantoea dispersa promoted P uptake into cassava (Manihot esculenta Crantz) roots due to the secretion of salicylic and benzene acetic acids for more effective $P$ solubilization. Root inoculation with $P$. dispersa also activated the natural soil microbial community in the rhizosphere. Such strains could be suitable for optimizing agro-microecological systems under P limitations. Finally, Castro et al. [136] used the mangrove endophytic Enterobacter sp. as an inoculum for the production of seedlings of $A$. polyphylla trees and found that the endophyte increased shoot dry mass and the fitness of the seedling.

c. Siderophore Production

Iron is essential for all life and is required as a co-factor of many essential enzymes, including the biochemical processes involved in nitrogen fixation in nodules. However, most soil iron is not available for plant absorption because it is present in extremely insoluble ferric $\left(\mathrm{Fe}^{3+}\right)$ forms of carbonates, hydroxides, oxides, and phosphates [137] in the soil. Under iron deficiency, many microorganisms can produce and secrete the low molecular weight siderophores, which bind $\mathrm{Fe}^{3+}, \mathrm{Fe}^{2+}$, and other divalent metal ions which are essential for plants [138]. Besides delivery to the plants, siderophores also participate in scavenging undesired metal ions in the rhizosphere to prevent uptake by the roots. These 
include $\mathrm{Zn}, \mathrm{Cd}, \mathrm{Cr}, \mathrm{Al}$, and $\mathrm{Pb}$ ions and, also radioactive ions such as $\mathrm{U}$ or $\mathrm{Np}$ to reduce toxicity for the plants [139]. Siderophores can also stimulate the plant-induced systematic resistant response to alleviate the toxicity of trace metals to plant growth [76].

Normally, endophytic bacteria produced siderophores only in soils with iron limitations [140]. Sabate et al. [83] showed this for siderophores produced by two endophytic Bacillus spp. strains, which, in promoted the growth of common bean under iron limitation. Siderophores of the bacterial endophytes also outcompete phytopathogen by binding the essential elements required for their propagation, thereby protecting the plants [141]. For instance, endophytic Bacillus spp. inhibit the growth of Fusarium oxysporum by absorbing $\mathrm{Fe}^{3+}$ from the environment through the secretion of siderophores. Lacava et al. [142] showed that the citrus endophyte Methylobacterium mesophilicum released hydroxamatetype siderophores into the medium. When the siderophore-containing supernatant was applied to Xylella fastidiosa subsp. pauca, it promoted the growth and chlorophyll content of the plants. Similar results were reported for various symbiotic interactions with different agriculturally relevant hosts in greenhouse experiments.

\section{Indirect Plant Growth Promotion}

\section{A. Stress Tolerance}

Plants are exposed to various stresses [143], which are the result of antagonistic or toxic substances in their environment, nutrient or essential ion limitations, or biotic stress inducers [144]. Both biotic and abiotic stresses contribute about $30-50 \%$ of the agricultural loss worldwide [145]. Temperature, salinity, drought, trace metals, flooding, and nutrient deficiency are considered the major abiotic stresses (Figure 5). Biotic stresses are induced by pathogenic microorganisms up to insects or nematodes. Therefore, future studies aim to develop eco-friendly technologies which increase plants' resistance to both abiotic and biotic stresses. A promising strategy is the generation of stronger and healthier plants with an improved immune system. Not surprisingly, endophytes have long been known to fulfill these criteria and provide excellent systems for agricultural application, as well as the identification of the molecular mechanisms by which they promote plant fitness. The microbial strategies range from the immediate activation of responsive systems which directly and specifically counteract the stress [146] and the production of anti-stress metabolites [147] that strengthens the plants, to a broad spectrum of immune responses which ultimately protect the plants better when exposed to different stresses. Understanding the mechanism behind these strategies may provide us with molecular and biochemical tools for agricultural applications.
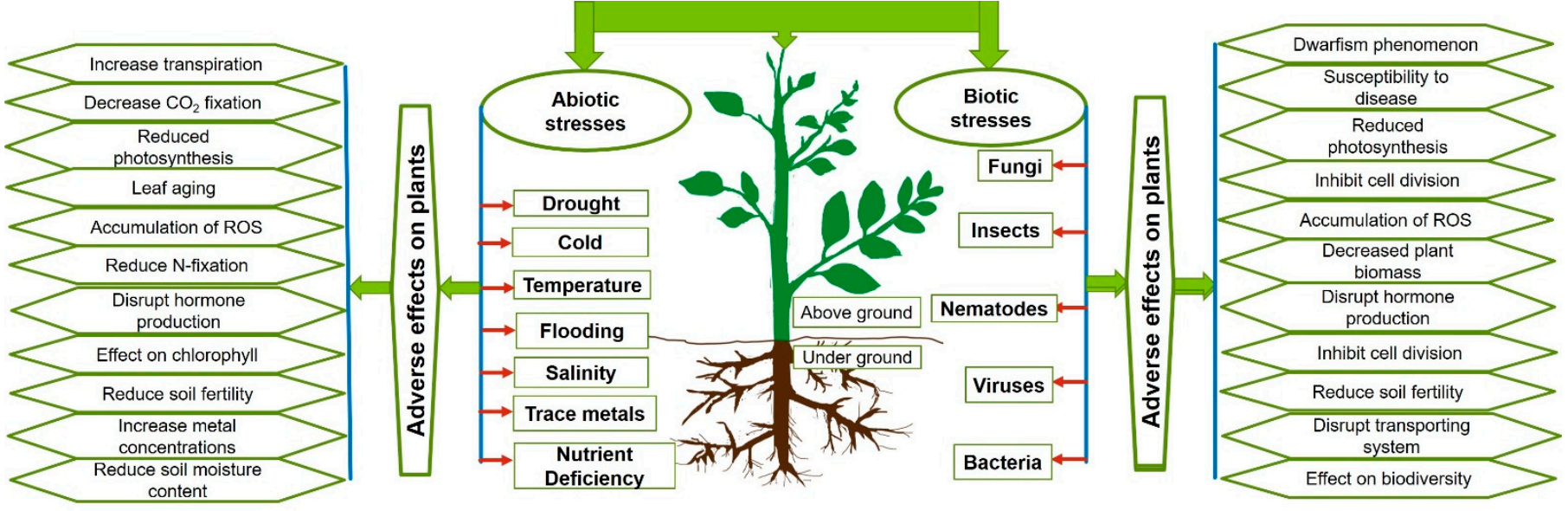

Figure 5. Biotic and abiotic stresses and their effects on plant growth. 
Endophytic bacteria support plants to combat drought stress via the production of volatile compounds, abscisic acid, ACC-deaminase, and IAA. Moreover, enhanced antioxidant activity and osmotic adjustment participate in the endophyte effects [148]. Razzaghi-Komaresofla et al. [149] introduced salinity-tolerant Staphylococcus sp. strains which improved the growth and salt tolerance of Salicornia sp. plants either individually or in combination. Endophyte-managed host resistance to pathogens also includes niche competition by the production of defensive metabolites such as antibiotics, antimicrobial, and structural compounds, as well as the induction of immunity or systemic resistance in the host plant [150].

Plants experiencing biotic and abiotic stress produce elevated concentrations of ethylene [151], which is are synthesized from ACC [152]. Production of the defense hormone ethylene restricts growth and hence affects the development of the plant in general [153]. Afridi et al. [154] reported the improved growth and stress tolerance of two wheat varieties inoculated with ACC-producing bacterial endophytes. An advantage of ethyleneproducing endophytes may be the local synthesis of the hormone in the symbiotic tissue, which might ensure that ethylene-induced defense occurs only in tissues that are exposed to stress. Endophyte-produced ACC-deaminase can alleviate the impact of elevated ethylene concentrations on stressful plants through the hydrolysis of ACC into $\alpha$-ketobutyrate and ammonia. The stressed plant could utilize the ammonia and energy liberated from ACC decomposition for growth $[155,156]$. Multiple combinations of the beneficial features of endophytes, such as combinations of ethylene, siderophore, or exopolysaccharide production; nitrogen fixation; and phosphate solubilization are important to strengthen the plants under stress or nutrient limitations $[148,157,158]$. Interestingly, some endophytic bacteria possess sigma factors (Table 4 ), which are used to change the expression of some genes under unfavorable conditions to reduce negative impacts [106]. Data represented in Table 4 showed some examples of stresses and the mechanisms utilized by bacterial endophytes to alleviate these stresses.

Table 4. List of some examples of stress conditions and the mechanisms of resistance/alleviation by specific bacterial endophytes.

\begin{tabular}{|c|c|c|c|c|}
\hline $\begin{array}{l}\text { Stress } \\
\text { Condition }\end{array}$ & $\begin{array}{c}\text { Bacterial } \\
\text { Endophytes Used }\end{array}$ & Plant Host & Effect/Mechanism of Resistance & References \\
\hline Drought stress & Azospirillum spp. & Maize & $\begin{array}{l}\text { - Accumulation of the abscisic acid that } \\
\text { regulated plant water balance and osmotic } \\
\text { stress tolerance }\end{array}$ & [78] \\
\hline Cold tolerance & $\begin{array}{c}\text { Burkholderia } \\
\text { phytofrmans PsJN }\end{array}$ & Grapevine plant & $\begin{array}{l}\text { - Altering the photosynthetic activity and } \\
\text { metabolism of carbohydrates involved in } \\
\text { cold stress tolerance } \\
\text { The bacterium promoted acclimation and } \\
\text { resulted in lower cell damage, higher } \\
\text { photosynthetic activity, and accumulation } \\
\text { of cold-stress-related metabolites such as } \\
\text { starch, proline, and phenolic compounds }\end{array}$ & {$[159,160]$} \\
\hline Drought stress & $\begin{array}{c}\text { Burkholderia } \\
\text { phytofirmans PsJN, } \\
\text { Enterobacter sp. PsJN }\end{array}$ & Maize & $\begin{array}{ll}- & \text { Minimized drought stress } \\
\text { - } & \text { Higher leaf relative water content }(30 \%) \\
\text { - } & \text { Lower leaf damage in terms of relative } \\
\text { - } & \text { membrane permeability } \\
\text { Increasing shoot biomass, root biomass, } \\
\text { leaf area, chlorophyll content, } \\
\text { photosynthesis, and the photochemical } \\
\text { efficiency of PSII }\end{array}$ & [161] \\
\hline
\end{tabular}


Table 4. Cont.

\begin{tabular}{|c|c|c|c|c|}
\hline $\begin{array}{l}\text { Stress } \\
\text { Condition }\end{array}$ & $\begin{array}{c}\text { Bacterial } \\
\text { Endophytes Used }\end{array}$ & Plant Host & Effect/Mechanism of Resistance & References \\
\hline Drought stress & $\begin{array}{l}\text { Gluconacetobacter } \\
\text { diazotrophicus }\end{array}$ & $\begin{array}{l}\text { Sugarcane } \\
\text { (Saccharum } \\
\text { officinarum)/shoot }\end{array}$ & $\begin{array}{ll}- & \text { Activation of different genes (ERD15 } \\
\text { - } & \text { PREB1A/CBF3 and DREB1B/CBF) } \\
- & \text { Production of plant hormones (IAA) } \\
- & \text { Activation of the ABA and ethylene } \\
\text { pathways }\end{array}$ & [162] \\
\hline Drought stress & $\begin{array}{l}\text { Pseudomonas } \\
\text { azotoformans }\end{array}$ & $\begin{array}{l}\text { Alyssum serpylli- } \\
\text { folium/leaves }\end{array}$ & $\begin{array}{ll}- & \text { Improve relative water content } \\
\text { - } & \text { Improve chlorophyll content } \\
\text { - } & \text { Improved oxidative enzyme production } \\
\text { - } & \text { ImpD, POD, and CAT) } \\
\text { - } & \text { Increase plant biomass }\end{array}$ & [163] \\
\hline Drought stress & $\begin{array}{c}\text { Bacillus } \\
\text { amyloliquifaciens }\end{array}$ & Grapevine/roots & $\begin{array}{ll}- & \text { Melatonin secretion } \\
- & \text { Reduced } \mathrm{MDA}, \mathrm{H}_{2} \mathrm{O}_{2}, \text { and } \mathrm{O}_{2}^{-}\end{array}$ & [164] \\
\hline Drought stress & Pantoea alhagi & $\begin{array}{l}\text { Alhagi sparsifolia/ } \\
\text { leaves }\end{array}$ & 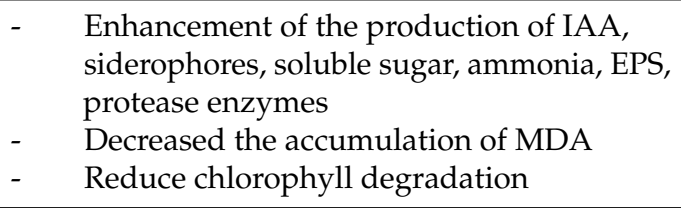 & [165] \\
\hline Drought stress & $\begin{array}{l}\text { Bacillus subtilis and } \\
\text { Paenibacillus } \\
\text { illinoinensi }\end{array}$ & $\begin{array}{l}\text { Capsicum } \\
\text { annuum/root }\end{array}$ & $\begin{array}{l}\text { Improvement total biomass, root length, } \\
\text { photosynthetic activity, proline contents, } \\
\text { transpiration, and cell turgor }\end{array}$ & [166] \\
\hline Drought stress & Bacillus pumilus & $\begin{array}{l}\text { Glycyrrhiza } \\
\text { uralensis }\end{array}$ & $\begin{array}{ll}- & \text { Improvement root length } \\
- & \text { Enhancement of oxidative enzymes (CAT) } \\
- & \text { Improvement of antioxidant activity (GPX) } \\
- & \text { Reduced accumulation of } \mathrm{MDA}, \mathrm{H}_{2} \mathrm{O}_{2} \\
& \text { and } \mathrm{O}_{2}^{-}\end{array}$ & [167] \\
\hline Drought stress & $\begin{array}{l}\text { Bacillus sp. strain } \\
\text { Acb9, Providencia sp. } \\
\text { strain Acb11, } \\
\text { Staphylococcus sp. } \\
\text { strain Acb12, } \\
\text { Staphylococcus sp. } \\
\text { strain Acb13 and } \\
\text { Staphylococcus sp. } \\
\text { strain Acb14 }\end{array}$ & Ananas comosus & $\begin{array}{ll}\text { - } & \text { Enhancement of shoot and root length, and } \\
\text { - } & \text { root numbers } \\
\text { - } & \text { Nitrogen fixation } \\
\text { - } & \text { ACC-deaminase synthesis. } \\
\text { - } & \text { Active metabolites have antifungal } \\
\text { activities }\end{array}$ & [168] \\
\hline Drought stress & Sinorhizobium meliloti & $\begin{array}{l}\text { Medicago } \\
\text { sativa/root }\end{array}$ & $\begin{array}{ll}\text { - } & \text { Induced the superoxide dismutase (SOD) } \\
\text { gene } \\
\text { - } \quad \text { Upregulation of FeSOD and CU/ZnSOD }\end{array}$ & [169] \\
\hline Salinity & $\begin{array}{l}\text { Pseudomonas } \\
\text { pseudoalcaligenes }\end{array}$ & Rice & $\begin{array}{l}\text { - Induced the accumulation of higher } \\
\text { concentrations of glycine betaine-like } \\
\text { compounds. }\end{array}$ & [170] \\
\hline Salinity & $\begin{array}{l}\text { Pseudomonas } \\
\text { fluorescens } \\
\text { YsS6 and P. migulae } \\
\text { 8R6 }\end{array}$ & Tomato plants & $\begin{array}{l}\text { - } \quad \begin{array}{l}\text { Reduced ethylene levels due to ACC } \\
\text { deaminase activity }\end{array} \\
\text { - } \quad \text { Higher gain of biomass and a greater } \\
\text { number of flowers and buds }\end{array}$ & [156] \\
\hline $\begin{array}{l}\text { Salinity and trace } \\
\text { metals }\end{array}$ & $\begin{array}{c}\text { Pseudomonas stutzeri } \\
\text { A1501 }\end{array}$ & Rice & $\begin{array}{l}\text { Enhancement of plant growth through } \\
\text { secretion of ACC deaminase }\end{array}$ & [171] \\
\hline
\end{tabular}


Table 4. Cont.

\begin{tabular}{|c|c|c|c|c|}
\hline $\begin{array}{l}\text { Stress } \\
\text { Condition }\end{array}$ & $\begin{array}{c}\text { Bacterial } \\
\text { Endophytes Used }\end{array}$ & Plant Host & Effect/Mechanism of Resistance & References \\
\hline Salinity & $\begin{array}{l}\text { Bacillus sp., Pantoea } \\
\text { sp., Marinobacterium } \\
\text { sp., Acinetobacter sp., } \\
\text { Enterobacter sp., } \\
\text { Pseudomonas sp., } \\
\text { Rhizobium sp. and } \\
\text { Sinorhizobium sp. }\end{array}$ & $\begin{array}{c}\text { Psoralea corylifolia } \\
\text { L. }\end{array}$ & $\begin{array}{ll}\text { - } & \text { Enhanced phytohormone production } \\
\text { (IAA) } \\
\text { - } \quad \text { Enhanced seed germination } \\
\text { - } \quad \text { Enhanced plant vigor index }\end{array}$ & [172] \\
\hline $\begin{array}{l}\text { Trace metal } \\
\text { (copper- } \\
\text { contaminated } \\
\text { soils) }\end{array}$ & $\begin{array}{l}\text { Pantoea agglomerans } \\
\text { Jp3-3 and } \\
\text { Achromobacter } \\
\text { xylosoxidans strain } \\
\text { Ax } 10\end{array}$ & Brassica sp & $\begin{array}{ll}\text { - } & \text { ACC deaminase production } \\
\text { - } & \text { Improved copper uptake by the plants }\end{array}$ & {$[173,174]$} \\
\hline Salinity & $\begin{array}{c}\text { Bacillus subtilis strain } \\
\text { BERA } 71\end{array}$ & $\begin{array}{l}\text { Acacia gerrardii } \\
\text { Benth./root }\end{array}$ & $\begin{array}{l}\text { - Inoculated into Cicer arietinum seeds and } \\
\text { enhanced their growth under saline } \\
\text { condition through enhanced plant biomass } \\
\text { production; enhanced photosynthetic } \\
\text { pigments; reduced ROS levels; enhanced } \\
\text { antioxidant enzymes (POD, CAT, } \\
\text { glutathione reductase); increased content } \\
\text { of total phenols; decreased accumulation } \\
\text { of sodium; increased accumulation of } \mathrm{N}, \mathrm{K}, \\
\mathrm{Ca} \text {, and } \mathrm{Mg} \text {; and accumulation of proline }\end{array}$ & [175] \\
\hline Salinity & $\begin{array}{c}\text { Curtobacterium } \\
\text { oceanosedimentum } \\
\text { strain SAK1, } \\
\text { Curtobacterium } \\
\text { luteum strain SAK2, } \\
\text { Enterobacter ludwigii } \\
\text { strain SAK5, Bacillus } \\
\text { cereus strain SA1, } \\
\text { Micrococcus } \\
\text { yunnanensis strain } \\
\text { SA2, Enterobacter } \\
\text { tabaci SA3 }\end{array}$ & $\begin{array}{l}\text { Oenothera biennis } \\
\text { L., Artemisia } \\
\text { princeps Pamp, } \\
\text { Chenopodium } \\
\text { ficifolium Smith, } \\
\text { and Echinochloa } \\
\text { crusgalli/roots }\end{array}$ & $\begin{array}{l}\text { - This endophytic bacterial species } \\
\text { inoculated into rice plants under salt stress } \\
\text { alleviate stress through enhanced } \\
\text { phytohormone production (IAA and } \\
\text { gibberellins), enhanced organic acid } \\
\text { production, reduced ABA content, } \\
\text { improved sugar and GSH contents, } \\
\text { improved flavin monooxygenase and } \\
\text { auxin efflux genes }\end{array}$ & [176] \\
\hline Salinity & $\begin{array}{l}\text { Bacillus spp., } \\
\text { Enterobacter spp. }\end{array}$ & $\begin{array}{l}\text { Thymus } \\
\text { vulgaris/leaves, } \\
\text { stems, and roots }\end{array}$ & $\begin{array}{l}\text { - Improvement of plant growth through the } \\
\text { production of auxins, nitrogen fixation, } \\
\text { phosphate solubilization, and extracellular } \\
\text { lytic enzyme activities } \\
\text { - } \quad \text { Reduced antioxidant enzymes in the } \\
\text { inoculated plant (tomato) } \\
\text { - Secretion active compounds against the } \\
\text { plant pathogen (F. oxysporumen) }\end{array}$ & [177] \\
\hline $\begin{array}{l}\text { Trace metals }(\mathrm{Cd} \text {, } \\
\mathrm{Zn}, \mathrm{Pb} \text {, and } \mathrm{Cu})\end{array}$ & $\begin{array}{l}\text { Mesorhizobium loti } \\
\text { HZ76 and } \\
\text { Agrobacterium } \\
\text { radiobacter } \mathrm{HZ6} 6\end{array}$ & $\begin{array}{l}\text { Robinia } \\
\text { pseudoacacia/root } \\
\text { nodules }\end{array}$ & $\begin{array}{ll}- & \text { Enhanced IAA production } \\
\text { - } & \text { Enhanced ACC deaminase } \\
\text { - } & \text { Production of siderophores } \\
\text { - } & \text { Enhanced plant biomass production }\end{array}$ & [178] \\
\hline
\end{tabular}


Table 4. Cont

\begin{tabular}{|c|c|c|c|c|c|}
\hline $\begin{array}{l}\text { Stress } \\
\text { Condition }\end{array}$ & $\begin{array}{l}\text { Bacterial } \\
\text { Endophytes Used }\end{array}$ & Plant Host & & Effect/Mechanism of Resistance & References \\
\hline $\begin{array}{l}\text { Trace metal }(\mathrm{Cd} \\
\quad \text { and } \mathrm{Ni})\end{array}$ & $\begin{array}{l}\text { Enterobacter ludwigii } \\
\text { strain SAK5 and } \\
\text { Exiguobacterium } \\
\text { indicum strain SA22 }\end{array}$ & - & - & $\begin{array}{l}\text { Enhanced plant growth in presence of } \\
\text { trace metal through upregulation of trace } \\
\text { metal resistance genes and increased ABA } \\
\text { concentrations }\end{array}$ & {$[179]$} \\
\hline Trace metal $(\mathrm{Ni})$ & $\begin{array}{l}\text { Stenotrophomonas sp. } \\
\text { S20, Pseudomonas sp. } \\
\text { P21, and } \\
\text { Sphingobium sp. S42 }\end{array}$ & Tamarix chinensis & - & $\begin{array}{l}\text { Enhanced IAA production, siderophore } \\
\text { production, and ACC deaminase }\end{array}$ & {$[180]$} \\
\hline
\end{tabular}

$\mathrm{O}_{2}{ }^{-}$, superoxide anion radical; $\mathrm{H}_{2} \mathrm{O}_{2}$, hydrogen peroxide; MDA, malondialdehyde; $\mathrm{SOD}$, sodium dehydrogenase; POD, peroxidase; CAT, catalase, ABA, abscisic acid; EPS, exopolysaccharide; GPX, glutathione peroxidase; ROS, reactive oxygen species.

\section{B. Endophyte-Based Phytoremediation}

Phytoremediation is a promising tool for cleaning soil, water and air of contaminants, and endophyte-assisted phytoremediation is used for metal bioremediation in the soil to allow or promote plant growth in previously contaminated soils [137]. Other investigations reported the use of endophytic remediation for contamination with organic contaminants [181], hydrocarbons [182], explosives [183], herbicides [184], tannery effluent [185], and uranium [186].

Eevers et al. [187] examined the effect of Enterobacter aerogenes UH1, Sphingomonas taxi $\mathrm{UH1}$, and Methylobacterium radiotolerans UH1 on the growth of zucchini plants on 2,2-bis(pchlorophenyl)-1,1-dichloro- ethylene (DDE)-contaminated fields. Plants inoculated with the three strains separately or in combination showed an increased weight. Mitter et al. [188] planted sweet white clover plants on soils contaminated with diesel (up to $20 \mathrm{mg} / \mathrm{kg}$ ). Plants inoculated with the hydrocarbon-degrading endophytes EA4-40 (Pantoea sp.), EA117 (Stenotrophomonas sp.), EA6-5 (Pseudomonas sp.), and EA2-30 (Flavobacterium sp.) showed increased biomass and successfully overcame the growth inhibition observed for noninoculated plants. Wu et al. [189] isolated the endophytic Bacillus safensis strain ZY16 from the roots of Chloris virgate. This strain exhibited multifunctional properties, including efficient degradation of the $C_{12}-C_{32} n$-alkanes of diesel oil and polycyclic aromatic hydrocarbons under hypersaline conditions, as well as production of biosurfactants, which resulted in stronger growth and biomass production in the inoculated plants compared with the controls. These studies indicated that bacterial endophytes have an important dynamic role in the management of abiotic stress and could efficiently be applied for environmental clean-up for sustainable agriculture development.

\section{Disease Control}

Currently, agrochemicals are considered the main method for combatting microbeinduced plant diseases; however, many of the applied substances have toxic effects on animals and humans. The application of endophytic bacteria is of great interest as an environmentally friendly alternative to agrochemicals [190].

Endophytes can restrict pathogen invasion into plants via direct and indirect mechanisms. The direct mechanism describes a competition between endophytes and phytopathogens in which the endophytes restrict pathogen growth, e.g., through the secretion of inhibitory metabolites. In the indirect mechanisms, the endophytes stimulate the plant's immune system or increase the plant's resistance toward the phytopathogens via upregulation of the defense genes [52]. Bacterial endophytes and phytopathogens have similar colonization patterns in the host plants and, consequently, they compete during invasion into host cells. Therefore, endophytes could be used as potential biocontrol agents to restrict pathogen entry into the host cell. The endophytic species Pseudomonas fluorescens and Pseudomonas aeruginosa produce 2, 4-diacetylphloroglucinol, penazine-1-carboxylic acid, pyoleutirin, pyrrolnitrin, or hydrogen cyanide, which suppress the growth of phytopathogenic 
fungi [191]. The most common endophytic bacterial species used in phytopathogen control are Bacillus species, since they produce lipopeptides, which hydrolyze fungal hyphal membranes [192,193]. The destabilization of the fungal membrane promotes nutrient leakage and hence reduces the virulence of fungi [191]. The indirect mechanisms include the stimulation of a jasmonate/ethylene-based defense response against necrotrophic microbes and a salicylic acid-based defense against biotrophic microorganisms [191,192].

D. Competition for Space and Nutrients

Niche competition means the competition of endophytes with deleterious pathogens for space and substrates. Blumenstein et al. [194] examined the competitive interaction between endophytes and the aggressive pathogen Ophiostoma novoulmi, which is the causative agent of the virulent Dutch elm disease. Based on the carbon utilization profiles, they showed that the endophytes showed extended niche overlap with the virulent pathogen; however, since the endophytes were more efficient at utilizing the applied carbon substrates, they were able to out-compete the pathogens. Another example described endophyte-produced siderophores that supplied sufficient iron to the endophytes but not the pathogen [195]. The chelated iron also became available to the host plant [52], which ultimately inhibited pathogen growth in the host plant by restricting mycelial growth and spore germination [196].

\section{a. Antibiosis}

Antibiosis is the synthesis and release of molecules that kill or inhibit the growth of the target phytopathogen [54], which results in plant disease control. The antibiotics and volatile organic compounds (VOCs) comprise ketones, alcohols, esters, terpenes, aldehydes, sulfur compounds, and lactones. VOCs, with their low molecular weights, can directly affect the growth of the phytopathogens at low concentrations, although the mechanisms are not well understood, since their perception systems are unknown [197,198]. Jasim et al. [199] reported the biosynthesis of iturin, surfactin, and fengycin by an endophyte Bacillus species from Bacopa monnieri. Besides toxic effects to pathogens, numerous endophytic bacterial VOCs control the symbiotic relationship in an extremely competitive environment for the host [200]. They might stimulate the propagation of the endophytes but not the pathogens.

\section{b. Parasitism}

Parasitism happens when one microbe feeds on another, e.g., a phytopathogen. This results in complete or partial lysis of its cellular structures. In particular, antagonistic bacteria feed on the fungal phytopathogen cell wall materials such as proteins, chitin, and glucans [201]. Bacteria form lipopolysaccharides and produce cell wall lytic enzymes for the infection of their hosts [202], and these cell wall lytic enzymes also cause hydrolysis of the cell wall of the fungal pathogen [203].

c. Induced Systemic Resistance (ISR)

Beneficial bacterial induce ISR in plants, which stimulates their local and systemic defensive responses, thus protecting the host against pathogen attacks. Besides the classical salicylic acid-based ISR, several endophytes also activate jasmonic acid- and ethyleneassisted immune responses [204]. An example of the latter mechanism includes the endophytic Bacillus velezensis YC7010, which confers systemic resistance in Arabidopsis seedlings against the insect pests Myzus persicae and the green peach aphid [205]. The different strategies are summarized in Table 5 and examples are provided in Figure 6. 
Table 5. Different strategies used by endophytic bacteria to resist phytopathogens.

\begin{tabular}{|c|c|c|}
\hline Strategy Used & Mechanisms & References \\
\hline $\begin{array}{l}\text { Competition for space } \\
\text { and nutrients }\end{array}$ & $\begin{array}{l}\text { Competitive root colonization, capacity to stick onto the root, differentiating } \\
\text { the growth phase, efficacy to utilize the organic acids existing in the root } \\
\text { exudates and hence synthesize different components }\end{array}$ & {$[206,207]$} \\
\hline $\begin{array}{l}\text { Competition with } \\
\text { ferric iron }\end{array}$ & $\begin{array}{l}\text { Siderophore production chelates ferric iron and hence reduces it for } \\
\text { pathogen growth. }\end{array}$ & [196] \\
\hline $\begin{array}{l}\text { Detoxification of } \\
\text { virulence factors }\end{array}$ & 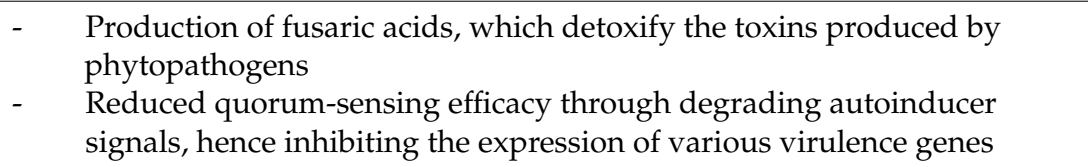 & {$[54,208]$} \\
\hline Antibiosis & $\begin{array}{l}\text { - Production of active compounds such as 2-hexyl-5-propyl resorcinol; } \\
\text { pyoluteorin, phenazines, and volatile hydrogen cyanide (HCN)-like } \\
\text { compounds; pyrrolnitrin; D-gluconic acid; 6-pentyl- } \alpha \text {-pyrone; and the } \\
\text { volatile 2,3-butanediol } \\
\text { - Production of active lipopeptide substances such as iturin, surfactin, } \\
\text { polymyxin, fengycin, and bacitracin. } \\
\text { Production of phenols, pyrrolnitrin, phloroglucinol, and volatile organic } \\
\text { compounds (VOCs) }\end{array}$ & {$[200,209-212]$} \\
\hline $\begin{array}{l}\text { Induced systemic } \\
\text { resistance (ISR) }\end{array}$ & $\begin{array}{l}\text { - ISR enhanced by the production of pyocyanin, salicylic acid, and } \\
\text { siderophores } \\
\text { - } \quad \text { ISR enhanced via the reaction between chemical elicitors such as chitosan } \\
\text { and their derivatives, and endophytic microbes } \\
\text { - } \quad \text { Production of antioxidant enzymes enhanced ISR }\end{array}$ & [213-216] \\
\hline
\end{tabular}

\subsection{Biotechnological Applications}

\subsubsection{Production of Bioactive Metabolites for Agricultural and Medical Applications}

Endophytic bacteria produce diverse bioactive metabolites that can be used in medicine as well as in agriculture for plant growth promotion and pesticides. The following examples describe some of the metabolites with biotechnological relevance.

\section{Pharmaceutical Applications}

Newman and Cragg [217] argued that endophytes produced approximately half of the new drugs introduced in the market from 1981 to 2010. They are used as insecticides, antioxidants, antimicrobial agents, anticancer, and antidiabetic compounds, among others (Figure 7) [218]. Many metabolites used as anticancer or antimicrobial agents have multiple targets in plants, animals, and human pathogens and offer many prospects in veterinary and medical therapy. Several of them are also considered eco-safe [219].

Medicinal plants have long been used to cure many diseases. More recently, it became obvious that many of their important chemical ingredients were derived from endophytes or the association of the medicinal plants with them. Alvin et al. [220] isolated endophytes from medicinal plants producing polyketides and small peptides, which displayed antituberculosis activity. The secondary metabolite profiles produced by Acinetobacter baumannii associated with Capsicum annuum L. uncovered phenolic compounds with peroxidant and antioxidant abilities [221]. Many peptides with antibacterial, antifungal, anticancer, immunosuppressive, and antimalarial properties have been identified, and several of them are interesting because of their target-specificities [222]. 


\section{Plant-Growth limitations}

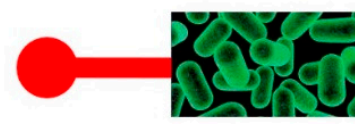

\section{Beneficial effects}

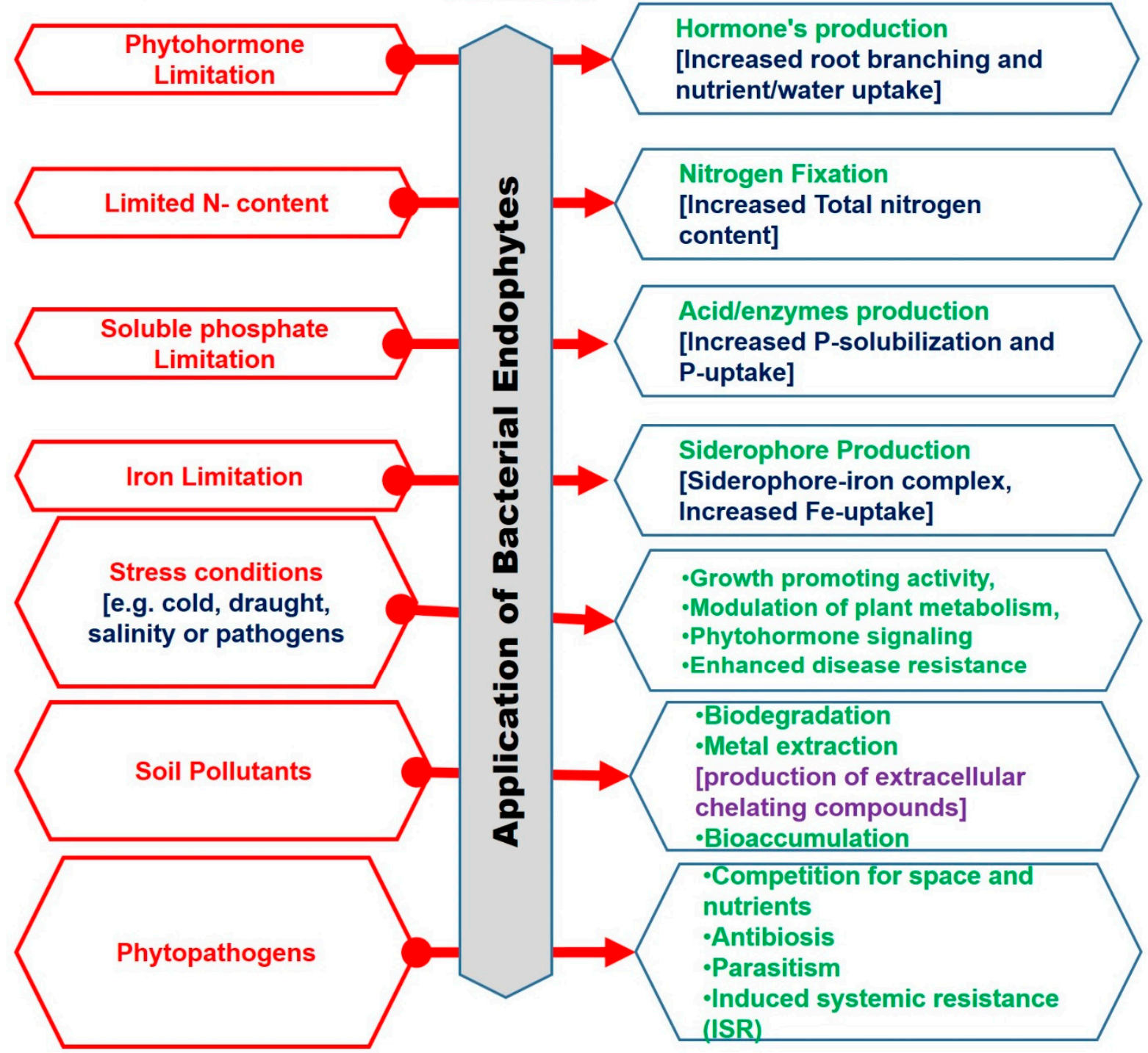

Figure 6. Challenges and benefits of bacterial endophyte utilization for applications in sustainable agriculture.

\subsubsection{Industrial Applications}

The extracellular hydrolytic enzymes produced by bacterial endophytes are required for host cell infection and triggering ISR [223]. The osmoregulation and antioxidant enzymes of the bacteria are involved in mitigating salinity stress on the metabolism of the host plant [224]. Microbial synthesis of biologically active compounds such as enzymes and secondary metabolites have been used for the manufacture of industrial products, including food and food supplements [225], biofuels [226], pharmaceuticals [227], detergents [228], and biopesticides [229].

For example, Ntabo et al. [230] isolated endophytic bacteria from Kenyan mangrove plants and showed that they produce proteases, pectinases, cellulases, amylases, and chitinases with putative industrial value. The endophytic Pseudomonas aeruginosa L10, associated with the roots of Phragmites australis, efficiently degraded hydrocarbons and produced a biosurfactant [231]. Baker et al. [232] studied endophytic bacteria associated with Coffea arabica L. and found that they could degrade caffeine, which has potential use in the decaffeination of beverages. 


\section{Products of Bacterial Endophytes}

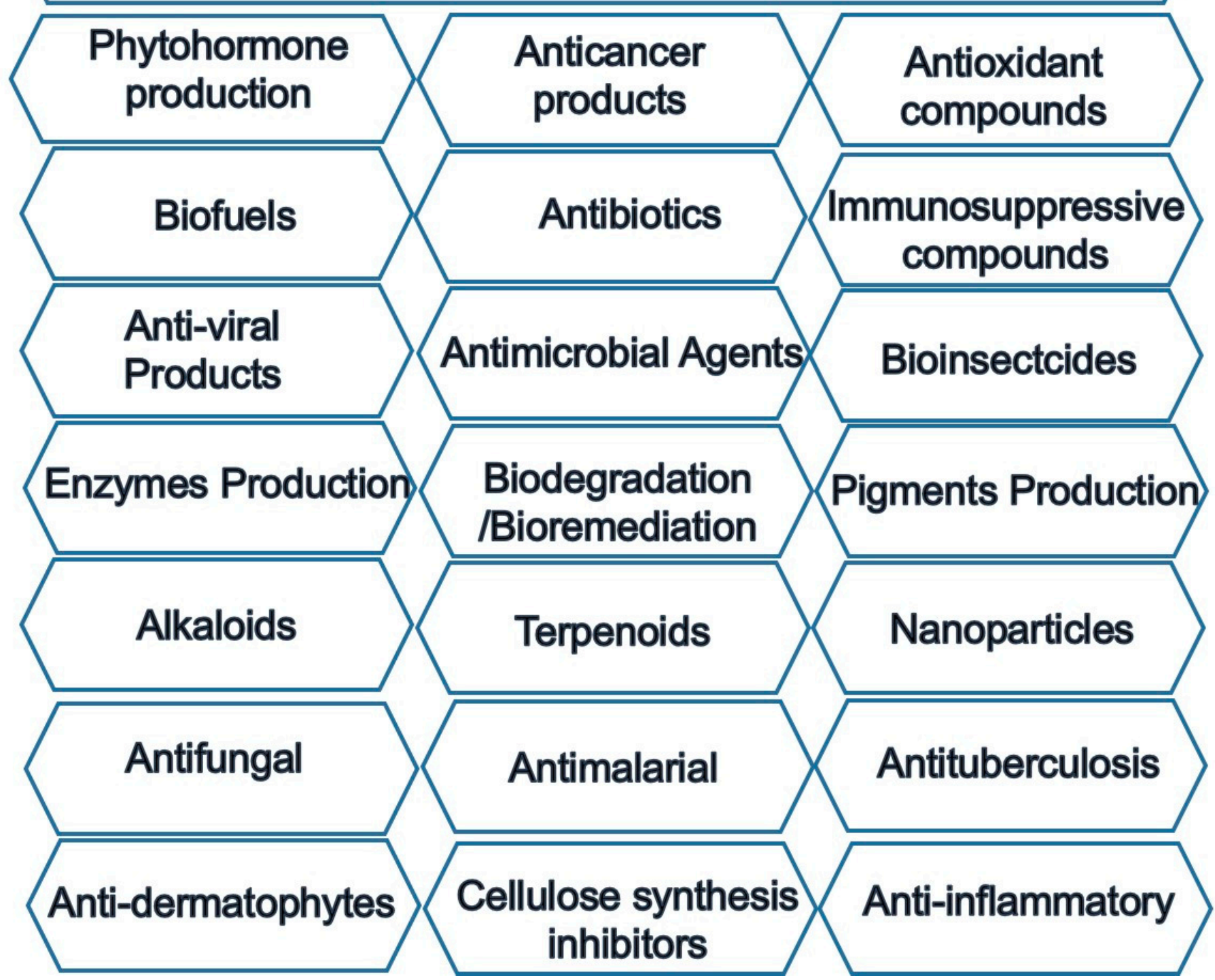

Figure 7. Diverse products produced by endophytic bacteria.

\subsubsection{Nano Biotechnology}

Nanoparticles have numerous technological and industrial applications in electronics, the energy industry, medicine, catalysis, and biotechnology [233-238]. Biological methods for the synthesis of nanoparticles provide many advantages over physical and chemical methods, avoiding the need for high energy and the absence of any toxic waste, which makes it simple, economical, and environmentally friendly [239-241].

Endophytic microbes reduce metallic ions for the production of nanoparticles [242] (Table 6). Low concentrations of nanosilver particles (AgNPs) synthesized by Pantoea ananatis showed antimicrobial activity against Candida albicans ATCC 10,231 and Bacillus cereus ATCC 10876, and higher concentrations were active against multidrug-resistant strains of Enterococcus faecium ATCC 700221, Escherichia coli NCTC 13351, Streptococcus pneumoniae ATCC 700677, and Staphylococcus aureus ATCC 33,592 [243]. AgNPs synthesized by endophytic Streptomyces spp. showed antimicrobial, antioxidant, and larvicidal activities [244]. The endophytic Streptomyces spp. isolated from medicinal plants synthesized Cu NPs and $\mathrm{CuO}$ NPs with antibacterial, antifungal, antioxidant, and insecticidal activities $[245,246]$. 
Table 6. Some recent examples of bacterial endophyte-mediated biosynthesis of nanoparticles and their activities.

\begin{tabular}{|c|c|c|c|c|}
\hline Nanoparticles & Bacterial Endophytes & Plant & Applications & References \\
\hline $\mathrm{Au}$ & Pseudomonas veronii & Annona squamosa & Antibacterial & [247] \\
\hline $\mathrm{Au}$ & Pseudomonas fluorescens 417 & Coffea arabica & Antibacterial & [248] \\
\hline $\mathrm{CaCl}_{2}$ & Lysinibacillus xylanilyticus & Chiliadenus montanus & Degradation of cellulase & [249] \\
\hline $\mathrm{Cu}$ & Streptomyces capillispiralis & Convolvulus arvensis & Antibacterial and antifungal & [245] \\
\hline $\mathrm{CuO}$ & $\begin{array}{l}\text { Streptomyces zaomyceticus and } \\
\text { Streptomyces pseudogriseolus }\end{array}$ & Oxalis corniculata $\mathrm{L}$. & $\begin{array}{c}\text { Antimicrobial, } \\
\text { antiphytopathogen, in vitro } \\
\text { cytotoxicity, larvicidal activity }\end{array}$ & [246] \\
\hline $\mathrm{MgO}$ & Streptomyces coelicolor & Ocimum sanctum & $\begin{array}{c}\text { Active against } \\
\text { multidrug-resistant microbes }\end{array}$ & [248] \\
\hline $\mathrm{ZnO}$ & Sphingobacterium thalpophilum & Withania somnifera (L.) & Antimicrobial & [250] \\
\hline $\mathrm{Ag}$ & Bacillus siamensis $\mathrm{C} 1$ & Coriandrum sativum & Antibacterial & [251] \\
\hline $\mathrm{Ag}$ & Pantoea ananatis & Monocot plants & Anti-multidrug-resistant & [243] \\
\hline $\mathrm{Ag}$ & Streptomyces laurentii R-1 & Achillea fragrantissima & $\begin{array}{l}\text { Antibacterial, in vitro } \\
\text { cytotoxicity, and textile industry }\end{array}$ & [252] \\
\hline $\mathrm{Ag}$ & Streptomyces antimycotics L-1 & Mentha longifolia L. & $\begin{array}{l}\text { Antibacterial, in vitro } \\
\text { cytotoxicity, and textile industry }\end{array}$ & [253] \\
\hline $\mathrm{Ag}$ & Pseudomonas poae $\mathrm{CO}$ & Allium sativum & Antifungal & [254] \\
\hline
\end{tabular}

\section{Conclusions and Future Prospective}

Biotechnology has proven to be applicable in many medical, industrial, and agricultural fields, as it is inexpensive and eco-friendly. Endophytes are plant symbionts; unlike the rhizosphere and phyllosphere bacteria that live on the plant's surface, endophytes find their way into the plants' endosphere to become protected from inappropriate environmental conditions. Recently, different advanced techniques such as clustered regularly interspaced short palindromic repeats (CRISPR)/Cas-mediated genome editing (GE) have been used to explain the plant-microbe interaction. These advanced techniques develop ideal plants/microbes that are relevant for agricultural applications. Endophytes produce several active metabolites that have positive effects on plant growth, leading to increased crop yields. Compared with agrochemicals, the presence of endophytes inside the host plant puts them in direct contact with the plant and becomes more effective. Chemicals are applied outside the plant, and a large part of them do not benefit the plant and cause pollution of the environment. Apart from the biotechnological uses of endophytes in sustainable agriculture, bacterial metabolites include other compounds that can be used in many technological and industrial applications, as well as their ability to reduce metal ions to nanoparticles, which can be used in technological, industrial, medical, and electronic applications. In the future, nanoparticles will be helpful in the formation of new nano-drugs, nano-pestcides, and nano-fertilizers to suppress plant pathogens and to increase the fertility of soils and plants through providing essential elements. Therefore, the mechanisms of fabricating specific shapes and sizes using eco-friendly microbes, including endophytes, require more research. Moreover, the integration of bacterial endophytes into different biomedical and biotechnological applications is still limited; therefore, it is urgent to discover new compounds from endophytic bacteria that have biological activities. Much research is still needed to understand endophytic bacteria and their relationships with plants, and to optimize the use of their premium metabolic products and formulate them into products that can be marketed for economic benefit. 
Author Contributions: Conceptualization, A.M.E., S.E.-D.H., S.S.S., and A.F.; methodology, A.M.E., M.A.A.-R., S.E.-D.H., and A.F.; software, A.M.E., M.A.A.-R., S.E.-D.H., S.S.S., A.E. (Albaraa Elsaied), A.E. (Amr Elkelish), and A.F.; validation, A.M.E., M.A.A.-R., S.E.-D.H., S.S.S., A.E. (Albaraa Elsaied), A.E. (Amr Elkelish), and A.F.; formal analysis, A.M.E., M.A.A.-R., S.E.-D.H., S.S.S., and A.F.; investigation, A.M.E., M.A.A.-R., S.E.-D.H., S.S.S., A.E. (Albaraa Elsaied), and A.F.; resources, A.M.E., M.A.A.-R., S.E.-D.H., S.S.S., A.E. (Albaraa Elsaied), A.E. (Amr Elkelish), and A.F.; data curation, A.M.E., M.A.A.-R., S.E.-D.H., S.S.S., A.E. (Albaraa Elsaied), A.E. (Amr Elkelish), and A.F.; writingoriginal draft preparation, A.M.E., M.A.A.-R., S.E.-D.H., S.S.S., R.O., A.E. (Albaraa Elsaied), A.E. (Amr Elkelish), and A.F.; writing-review and editing, A.M.E., M.A.A.-R., S.E.-D.H., S.S.S., A.E. (Albaraa Elsaied), R.O., M.H., A.E. (Amr Elkelish), and A.F.; visualization, A.M.E., M.A.A.-R., S.E.D.H., S.S.S., A.E. (Albaraa Elsaied), A.E. (Amr Elkelish), and A.F.; supervision, A.M.E., M.A.A.-R., S.E.-D.H., S.S.S., and A.F.; project admin-istration, S.E.-D.H., and A.F.; funding acquisition, S.E.-D.H., M.H., and A.B. All authors have read and agreed to the published version of the manuscript.

Funding: This research received no external funding.

Institutional Review Board Statement: Not applicable.

Informed Consent Statement: Not applicable.

Data Availability Statement: The data presented in this study are available on request from the corresponding author.

Conflicts of Interest: The authors declare no conflict of interest.

\section{References}

1. Tidke, S.A.; Kiran, S.; Giridhar, P.; Gokare, R.A. Current Understanding and Future Perspectives of Endophytic Microbes vis-a-vis Production of Secondary Metabolites. In Endophytes and Secondary Metabolites; Jha, S., Ed.; Springer International Publishing: Cham, Switzerland, 2018; pp. 1-16.

2. Fouda, A.H.; Hassan, S.E.-D.; Eid, A.M.; Ewais, E.E.-D. Biotechnological applications of fungal endophytes associated with medicinal plant Asclepias sinaica (Bioss.). Ann. Agric. Sci. 2015, 60, 95-104. [CrossRef]

3. Strobel, G. The Emergence of Endophytic Microbes and Their Biological Promise. J. Fungi 2018, 4, 57. [CrossRef]

4. Khalil, A.M.A.; Hassan, S.E.-D.; Alsharif, S.M.; Eid, A.M.; Ewais, E.E.-D.; Azab, E.; Gobouri, A.A.; Elkelish, A.; Fouda, A. Isolation and Characterization of Fungal Endophytes Isolated from Medicinal Plant Ephedra pachyclada as Plant Growth-Promoting. Biomolecules 2021, 11, 140. [CrossRef] [PubMed]

5. Eid, A.M.; Salim, S.S.; Hassan, S.E.-D.; Ismail, M.A.; Fouda, A. Role of Endophytes in Plant Health and Abiotic Stress Management. In Microbiome in Plant Health and Disease: Challenges and Opportunities; Kumar, V., Prasad, R., Kumar, M., Choudhary, D.K., Eds.; Springer: Singapore, 2019; pp. 119-144.

6. Golinska, P.; Wypij, M.; Agarkar, G.; Rathod, D.; Dahm, H.; Rai, M. Endophytic actinobacteria of medicinal plants: Diversity and bioactivity. Antonie Van Leeuwenhoek 2015, 108, 267-289. [CrossRef]

7. Sun, H.; He, Y.; Xiao, Q.; Ye, R.; Tian, Y. Isolation, characterization, and antimicrobial activity of endophytic bacteria from Polygonum cuspidatum. Afr. J. Microbiol. Res. 2013, 7, 1496-1504. [CrossRef]

8. Hollants, J.; Leroux, O.; Leliaert, F.; Decleyre, H.; De Clerck, O.; Willems, A. Who Is in There? Exploration of Endophytic Bacteria within the Siphonous Green Seaweed Bryopsis (Bryopsidales, Chlorophyta). PLoS ONE 2011, 6, e26458. [CrossRef] [PubMed]

9. Rangjaroen, C.; Sungthong, R.; Rerkasem, B.; Teaumroong, N.; Noisangiam, R.; Lumyong, S. Untapped Endophytic Colonization and Plant Growth-Promoting Potential of the Genus Novosphingobium to Optimize Rice Cultivation. Microbes Environ. 2017, 32, 84-87. [CrossRef] [PubMed]

10. Castanheira, N.L.; Dourado, A.C.; Pais, I.; Semedo, J.; Scotti-Campos, P.; Borges, N.; Carvalho, G.; Crespo, M.T.B.; Fareleira, P. Colonization and beneficial effects on annual ryegrass by mixed inoculation with plant growth promoting bacteria. Microbiol. Res. 2017, 198, 47-55. [CrossRef]

11. Mercado-Blanco, J.; Lugtenberg, B.J.J. Biotechnological Applications of Bacterial Endophytes. Curr. Biotechnol. 2014, 3, 60-75. [CrossRef]

12. Hardoim, P.R.; van Overbeek, L.S.; Elsas, J.D.v. Properties of bacterial endophytes and their proposed role in plant growth. Trends Microbiol. 2008, 16, 463-471. [CrossRef]

13. Abreu-Tarazi, M.F.; Navarrete, A.A.; Andreote, F.D.; Almeida, C.V.; Tsai, S.M.; Almeida, M. Endophytic bacteria in long-term in vitro cultivated "axenic" pineapple microplants revealed by PCR-DGGE. World J. Microbiol. Biotechnol. 2010, 26, 555-560. [CrossRef]

14. Li, J.; Zheng, B.; Hu, R.; Liu, Y.; Jing, Y.; Xiao, Y.; Sun, M.; Chen, W.; Zhou, Q. Pseudomonas species isolated from tobacco seed promote root growth and reduce lead contents in Nicotiana tobacum K326. Can J Microbiol 2019, 65, 214-223. [CrossRef] [PubMed]

15. Annapurna, K.; Govindasamy, V.; Sharma, M.; Ghosh, A.; Chikara, S.K. Whole genome shotgun sequence of Bacillus paralicheniformis strain KMS 80, a rhizobacterial endophyte isolated from rice (Oryza sativa L.). 3 Biotech 2018, 8, 223. [CrossRef] 
16. Zhu, Y.; She, X. Evaluation of the plant-growth-promoting abilities of endophytic bacteria from the psammophyte Ammodendron bifolium. Can. J. Microbiol. 2018, 64, 253-264. [CrossRef] [PubMed]

17. Mareque, C.; da Silva, T.F.; Vollú, R.E.; Beracochea, M.; Seldin, L.; Battistoni, F. The Endophytic Bacterial Microbiota Associated with Sweet Sorghum (Sorghum bicolor) Is Modulated by the Application of Chemical N Fertilizer to the Field. Int. J. Genom. 2018, 2018, 7403670. [CrossRef] [PubMed]

18. Gonzalez-Escobedo, R.; Briones-Roblero, C.I.; Pineda-Mendoza, R.M.; Rivera-Orduña, F.N.; Zúñiga, G. Bacteriome from Pinus arizonica and P. durangensis: Diversity, Comparison of Assemblages, and Overlapping Degree with the Gut Bacterial Community of a Bark Beetle That Kills Pines. Front. Microbiol. 2018, 9. [CrossRef]

19. Nguyen, H.Q.; Vu, N.T.-H.; Chu, H.H.; Chu, S.K.; Hoang, H.; Tran, T.T.; Nguyen, C.; Dinh, L.T.-M.; Trinh, H.T.-T.; Phi, T.Q. Draft Genome Sequence of Streptomyces cavourensis YBQ59, an Endophytic Producer of Antibiotics Bafilomycin D, Nonactic Acid, Prelactone B, and 5,11-Epoxy-10-Cadinanol. Microbiol. Resour. Announc. 2018, 7, e01056-18. [CrossRef]

20. Asaf, S.; Khan, A.L.; Khan, M.A.; Al-Harrasi, A.; Lee, I.-J. Complete genome sequencing and analysis of endophytic Sphingomonas sp. LK11 and its potential in plant growth. 3 Biotech 2018, 8, 389. [CrossRef] [PubMed]

21. Haidar, B.; Ferdous, M.; Fatema, B.; Ferdous, A.S.; Islam, M.R.; Khan, H. Population diversity of bacterial endophytes from jute (Corchorus olitorius) and evaluation of their potential role as bioinoculants. Microbiol. Res. 2018, 208, 43-53. [CrossRef]

22. Verma, S.K.; White, J.F. Indigenous endophytic seed bacteria promote seedling development and defend against fungal disease in browntop millet (Urochloa ramosa L.). J. Appl. Microbiol. 2018, 124, 764-778. [CrossRef]

23. de Almeida Lopes, K.B.; Carpentieri-Pipolo, V.; Fira, D.; Balatti, P.A.; López, S.M.Y.; Oro, T.H.; Stefani Pagliosa, E.; Degrassi, G. Screening of bacterial endophytes as potential biocontrol agents against soybean diseases. J. Appl. Microbiol. 2018, 125, $1466-1481$. [CrossRef] [PubMed]

24. Bind, M.; Nema, S. Isolation and Molecular Characterization of Endophytic Bacteria from Pigeon Pea along with Antimicrobial Evaluation against Fusarium udum. Appl. Microbiol. Open Access 2019, 5, 163. [CrossRef]

25. Soldan, R.; Mapelli, F.; Crotti, E.; Schnell, S.; Daffonchio, D.; Marasco, R.; Fusi, M.; Borin, S.; Cardinale, M. Bacterial endophytes of mangrove propagules elicit early establishment of the natural host and promote growth of cereal crops under salt stress. Microbiol. Res. 2019, 223-225, 33-43. [CrossRef] [PubMed]

26. Brígido, C.; Singh, S.; Menéndez, E.; Tavares, M.J.; Glick, B.R.; Félix, M.d.R.; Oliveira, S.; Carvalho, M. Diversity and Functionality of Culturable Endophytic Bacterial Communities in Chickpea Plants. Plants 2019, 8, 42. [CrossRef] [PubMed]

27. Chen, L.; Wu, Y.D.; Chong, X.Y.; Xin, Q.H.; Wang, D.X.; Bian, K. Seed-borne endophytic Bacillus velezensis LHSB1 mediate the biocontrol of peanut stem rot caused by Sclerotium rolfsii. J. Appl. Microbiol. 2020, 128, 803-813. [CrossRef]

28. Aquino, J.P.A.D.; Macedo Junior, F.B.D.; Antunes, J.E.L.; Figueiredo, M.D.V.B.; Alcântara Neto, F.D.; Araujo, A.S.F.D. Plant growth-promoting endophytic bacteria on maize and sorghum. Pesqui. Agropecuária Trop. 2019, 49. [CrossRef]

29. Woźniak, M.; Gałązka, A.; Tyśkiewicz, R.; Jaroszuk-Ściseł, J. Endophytic Bacteria Potentially Promote Plant Growth by Synthesizing Different Metabolites and their Phenotypic/Physiological Profiles in the Biolog GEN III MicroPlateTM Test. Int. J. Mol. Sci. 2019, 20, 5283. [CrossRef]

30. Zhou, J.; Li, P.; Meng, D.; Gu, Y.; Zheng, Z.; Yin, H.; Zhou, Q.; Li, J. Isolation, characterization and inoculation of Cd tolerant rice endophytes and their impacts on rice under Cd contaminated environment. Environ. Pollut. 2020, 260, 113990. [CrossRef]

31. Borah, A.; Thakur, D. Phylogenetic and Functional Characterization of Culturable Endophytic Actinobacteria Associated With Camellia spp. for Growth Promotion in Commercial Tea Cultivars. Front. Microbiol. 2020, 11, 318. [CrossRef]

32. Herrera, H.; Sanhueza, T.; Novotná, A.; Charles, T.C.; Arriagada, C. Isolation and Identification of Endophytic Bacteria from Mycorrhizal Tissues of Terrestrial Orchids from Southern Chile. Diversity 2020, 12, 55. [CrossRef]

33. Gamalero, E.; Favale, N.; Bona, E.; Novello, G.; Cesaro, P.; Massa, N.; Glick, B.R.; Orozco-Mosqueda, M.d.C.; Berta, G.; Lingua, G. Screening of Bacterial Endophytes Able to Promote Plant Growth and Increase Salinity Tolerance. Appl. Sci. 2020, $10,5767$. [CrossRef]

34. Khan, M.S.; Gao, J.; Chen, X.; Zhang, M.; Yang, F.; Du, Y.; Moe, T.S.; Munir, I.; Xue, J.; Zhang, X. Isolation and Characterization of Plant Growth-Promoting Endophytic Bacteria Paenibacillus polymyxa SK1 from Lilium lancifolium. Biomed Res. Int. 2020, 2020, 8650957. [CrossRef]

35. Khaskheli, M.A.; Wu, L.; Chen, G.; Chen, L.; Hussain, S.; Song, D.; Liu, S.; Feng, G. Isolation and Characterization of RootAssociated Bacterial Endophytes and Their Biocontrol Potential against Major Fungal Phytopathogens of Rice (Oryza sativa L.). Pathogens 2020, 9, 172. [CrossRef]

36. ALKahtani, M.D.F.; Fouda, A.; Attia, K.A.; Al-Otaibi, F.; Eid, A.M.; Ewais, E.E.-D.; Hijri, M.; St-Arnaud, M.; Hassan, S.E.-D.; Khan, N.; et al. Isolation and Characterization of Plant Growth Promoting Endophytic Bacteria from Desert Plants and Their Application as Bioinoculants for Sustainable Agriculture. Agronomy 2020, 10, 1325. [CrossRef]

37. Schirawski, J.; Perlin, M.H. Plant-Microbe Interaction 2017-The Good, the Bad and the Diverse. Int. J. Mol. Sci. 2018, 19, 1374. [CrossRef]

38. Hassan, S.E.-D. Plant growth-promoting activities for bacterial and fungal endophytes isolated from medicinal plant of Teucrium polium L. J Adv Res 2017, 8, 687-695. [CrossRef]

39. Doty, S.L. Symbiotic Plant-Bacterial Endospheric Interactions. Microorganisms 2018, 6, 28. [CrossRef]

40. Afzal, I.; Shinwari, Z.K.; Sikandar, S.; Shahzad, S. Plant beneficial endophytic bacteria: Mechanisms, diversity, host range and genetic determinants. Microbiol. Res. 2019, 221, 36-49. [CrossRef] 
41. Nair, D.N.; Padmavathy, S. Impact of Endophytic Microorganisms on Plants, Environment and Humans. Sci. World J. 2014, 2014, 250693. [CrossRef]

42. Rosenblueth, M.; Martínez-Romero, E. Bacterial Endophytes and Their Interactions with Hosts. Mol. Plant-Microbe Interact. 2006, 19, 827-837. [CrossRef]

43. Kandel, S.L.; Joubert, P.M.; Doty, S.L. Bacterial Endophyte Colonization and Distribution within Plants. Microorganisms 2017, 5. [CrossRef]

44. Balsanelli, E.; Serrato, R.V.; De Baura, V.A.; Sassaki, G.; Yates, M.G.; Rigo, L.U.; Pedrosa, F.O.; De Souza, E.M.; Monteiro, R.A. Herbaspirillum seropedicae $\mathrm{rbB}$ and $\mathrm{rfbC}$ genes are required for maize colonization. Environ. Microbiol. 2010, 12, 2233-2244. [PubMed]

45. Reinhold-Hurek, B.; Maes, T.; Gemmer, S.; Van Montagu, M.; Hurek, T. An Endoglucanase Is Involved in Infection of Rice Roots by the Not-Cellulose-Metabolizing Endophyte Azoarcus Sp. Strain BH72. Mol. Plant-Microbe Interact. 2006, 19, 181-188. [CrossRef] [PubMed]

46. Fouda, A.; Abdel-Maksoud, G.; Saad, H.A.; Gobouri, A.A.; Mohammedsaleh, Z.M.; El-Sadany, M.A. The efficacy of silver nitrate $\left(\mathrm{AgNO}_{3}\right)$ as a coating agentto protect paper against high deteriorating microbes. Catalysts 2021, 11, 310. [CrossRef]

47. Suárez-Moreno, Z.R.; Devescovi, G.; Myers, M.; Hallack, L.; Mendonça-Previato, L.; Caballero-Mellado, J.; Venturi, V. Commonalities and Differences in Regulation of N-Acyl Homoserine Lactone Quorum Sensing in the Beneficial Plant-Associated Burkholderia Species Cluster. Appl. Environ. Microbiol. 2010, 76, 4302. [CrossRef]

48. Compant, S.; Reiter, B.; Sessitsch, A.; Nowak, J.; Clément, C.; Ait Barka, E. Endophytic Colonization of Vitis vinifera L. by Plant Growth-Promoting Bacterium Burkholderia sp. Strain PsJN. Appl. Environ. Microbiol. 2005, 71, 1685. [CrossRef] [PubMed]

49. Prieto, P.; Schilirò, E.; Maldonado-González, M.M.; Valderrama, R.; Barroso-Albarracín, J.B.; Mercado-Blanco, J. Root hairs play a key role in the endophytic colonization of olive roots by Pseudomonas spp. with biocontrol activity. Microb. Ecol. 2011, 62, 435-445. [CrossRef]

50. White, J.F., Jr.; Torres, M.S.; Somu, M.P.; Johnson, H.; Irizarry, I.; Chen, Q.; Zhang, N.; Walsh, E.; Tadych, M.; Bergen, M. Hydrogen peroxide staining to visualize intracellular bacterial infections of seedling root cells. Microsc. Res. Tech. 2014, 77, 566-573. [CrossRef]

51. Paungfoo-Lonhienne, C.; Rentsch, D.; Robatzek, S.; Webb, R.I.; Sagulenko, E.; Näsholm, T.; Schmidt, S.; Lonhienne, T.G.A. Turning the Table: Plants Consume Microbes as a Source of Nutrients. PLoS ONE 2010, 5, e11915. [CrossRef]

52. Hardoim, P.R.; van Overbeek, L.S.; Berg, G.; Pirttilä, A.M.; Compant, S.; Campisano, A.; Döring, M.; Sessitsch, A. The Hidden World within Plants: Ecological and Evolutionary Considerations for Defining Functioning of Microbial Endophytes. Microbiol. Mol. Biol. Rev. 2015, 79, 293. [CrossRef]

53. Kandel, S.L.; Herschberger, N.; Kim, S.H.; Doty, S.L. Diazotrophic Endophytes of Poplar and Willow for Growth Promotion of Rice Plants in Nitrogen-Limited Conditions. Crop Sci. 2015, 55, 1765-1772. [CrossRef]

54. Compant, S.; Duffy, B.; Nowak, J.; Clément, C.; Barka, E.A. Use of plant growth-promoting bacteria for biocontrol of plant diseases: Principles, mechanisms of action, and future prospects. Appl. Environ. Microbiol. 2005, 71, 4951-4959. [CrossRef] [PubMed]

55. Mitter, B.; Pfaffenbichler, N.; Flavell, R.; Compant, S.; Antonielli, L.; Petric, A.; Berninger, T.; Naveed, M.; Sheibani-Tezerji, R.; von Maltzahn, G.; et al. A New Approach to Modify Plant Microbiomes and Traits by Introducing Beneficial Bacteria at Flowering into Progeny Seeds. Front. Microbiol. 2017, 8, 11. [CrossRef] [PubMed]

56. Glassner, H.; Zchori-Fein, E.; Yaron, S.; Sessitsch, A.; Sauer, U.; Compant, S. Bacterial niches inside seeds of Cucumis melo L. Plant Soil 2018, 422, 101-113. [CrossRef]

57. Koskimäki, J.J.; Pirttilä, A.M.; Ihantola, E.-L.; Halonen, O.; Frank, A.C. The Intracellular Scots Pine Shoot Symbiont Methylobacterium extorquens DSM13060 Aggregates around the Host Nucleus and Encodes Eukaryote-Like Proteins. mBio 2015, 6, e00039-15. [CrossRef] [PubMed]

58. Thomas, P.; Reddy, K.M. Microscopic elucidation of abundant endophytic bacteria colonizing the cell wall-plasma membrane peri-space in the shoot-tip tissue of banana. AOB Plants 2013, 5. [CrossRef]

59. Santoyo, G.; Moreno-Hagelsieb, G.; del Carmen Orozco-Mosqueda, M.; Glick, B.R. Plant growth-promoting bacterial endophytes. Microbiol. Res. 2016, 183, 92-99. [CrossRef] [PubMed]

60. Damam, M.; Kaloori, K.; Gaddam, B.; Kausar, R. Plant growth promoting substances (phytohormones) produced by rhizobacterial strains isolated from the rhizosphere of medicinal plants. Int. J. Pharm. Sci. Rev. Res. 2016, 37, 130-136.

61. Selim, M.T.; Salem, S.S.; Mohamed, A.A.; El-Gamal, M.S.; Awad, M.F.; Fouda, A. Biological treatment of real textile effulent using Aspergillus flavus and Fusarium oxysorium and their consortium along with the evaluation of their phytotoxicity. J. Fungi. 2021, 7, 193. [CrossRef]

62. Shahzad, R.; Waqas, M.; Khan, A.L.; Asaf, S.; Khan, M.A.; Kang, S.-M.; Yun, B.-W.; Lee, I.-J. Seed-borne endophytic Bacillus amyloliquefaciens RWL-1 produces gibberellins and regulates endogenous phytohormones of Oryza sativa. Plant Physiol. Biochem. 2016, 106, 236-243. [CrossRef]

63. Brader, G.; Compant, S.; Mitter, B.; Trognitz, F.; Sessitsch, A. Metabolic potential of endophytic bacteria. Curr. Opin. Biotechnol. 2014, 27, 30-37. [CrossRef] [PubMed]

64. Reinhold-Hurek, B.; Hurek, T. Living inside plants: Bacterial endophytes. Curr. Opin. Plant Biol. 2011, 14, 435-443. [CrossRef] [PubMed] 
65. Asgher, M.; Khan, M.I.R.; Anjum, N.A.; Khan, N.A. Minimising toxicity of cadmium in plants—Role of plant growth regulators. Protoplasma 2015, 252, 399-413. [CrossRef]

66. Spaepen, S.; Vanderleyden, J. Auxin and plant-microbe interactions. Cold Spring Harb. Perspect. Biol. 2011, 3, a001438. [CrossRef] [PubMed]

67. Ismail, M.A.; Amin, M.A.; Eid, A.M.; Hassan, S.E.-D.; Mahgoub, H.A.M.; Lashin, I.; Abdelwahab, A.T.; Azab, E.; Gobouri, A.A.; ElKelish, A.; et al. Comparative Study between Exogenously Applied Plant Growth Hormones versus Metabolites of Microbial Endophytes as Plant Growth-Promoting for Phaseolus vulgaris L. Cells 2021, 10, 1059. [CrossRef]

68. Rashid, S.; Charles, T.C.; Glick, B.R. Isolation and characterization of new plant growth-promoting bacterial endophytes. Appl. Soil Ecol. 2012, 61, 217-224. [CrossRef]

69. Duca, D.; Lorv, J.; Patten, C.L.; Rose, D.; Glick, B.R. Indole-3-acetic acid in plant-microbe interactions. Antonie Van Leeuwenhoek 2014, 106, 85-125. [CrossRef]

70. Apine, O.; Jadhav, J. Optimization of medium for indole-3-acetic acid production using Pantoea agglomerans strain PVM. J. Appl. Microbiol. 2011, 110, 1235-1244. [CrossRef]

71. Costacurta, A.; Vanderleyden, J. Synthesis of phytohormones by plant-associated bacteria. Crit. Rev. Microbiol. 1995, 21, 1-18. [CrossRef]

72. Fouda, A.; Eid, A.M.; Elsaied, A.; El-Belely, E.F.; Barghoth, M.G.; Azab, E.; Gobouri, A.A.; Hassan, S.E.-D. Plant Growth-Promoting Endophytic Bacterial Community Inhabiting the Leaves of Pulicaria incisa (Lam.) DC Inherent to Arid Regions. Plants 2021, 10, 76 [CrossRef] [PubMed]

73. Sun, L.; Wang, X.; Li, Y. Increased plant growth and copper uptake of host and non-host plants by metal-resistant and plant growth-promoting endophytic bacteria. Int. J. Phytoremediation 2016, 18, 494-501. [CrossRef]

74. Sun, Y.; Cheng, Z.; Glick, B.R. The presence of a 1-aminocyclopropane-1-carboxylate (ACC) deaminase deletion mutation alters the physiology of the endophytic plant growth-promoting bacterium Burkholderia phytofirmans PsJN. FEMS Microbiol. Lett. 2009, 296, 131-136. [CrossRef]

75. Albermann, S.; Linnemannstöns, P.; Tudzynski, B. Strategies for strain improvement in Fusarium fujikuroi: Overexpression and localization of key enzymes of the isoprenoid pathway and their impact on gibberellin biosynthesis. Appl. Microbiol. Biotechnol. 2013, 97, 2979-2995. [CrossRef]

76. Rana, K.L.; Kour, D.; Kaur, T.; Devi, R.; Yadav, A.N.; Yadav, N.; Dhaliwal, H.S.; Saxena, A.K. Endophytic microbes: Biodiversity, plant growth-promoting mechanisms and potential applications for agricultural sustainability. Antonie Van Leeuwenhoek 2020, 113, 1075-1107. [CrossRef] [PubMed]

77. Kieber, J.J. Tribute to Folke Skoog: Recent Advances in our Understanding of Cytokinin Biology. J. Plant Growth Regul. 2002, 21, 1-2. [CrossRef]

78. Cohen, A.C.; Travaglia, C.N.; Bottini, R.; Piccoli, P.N. Participation of abscisic acid and gibberellins produced by endophytic Azospirillum in the alleviation of drought effects in maize. Botany 2009, 87, 455-462. [CrossRef]

79. Bhore, S.J.; Ravichantar, N.; Loh, C.Y. Screening of endophytic bacteria isolated from leaves of Sambung nyawa [Gynura procumbens (Lour.) Merr.] for cytokinin-like compounds. Bioinformation 2010, 5, 191-197. [CrossRef]

80. Arkhipova, T.; Veselov, S.; Melentiev, A.; Martynenko, E.; Kudoyarova, G. Ability of bacterium Bacillus subtilis to produce cytokinins and to influence the growth and endogenous hormone content of lettuce plants. Plant Soil 2005, 272, 201-209. [CrossRef]

81. Peña-Yam, L.P.; Ruíz-Sánchez, E.; Barboza-Corona, J.E.; Reyes-Ramírez, A. Isolation of mexican Bacillus species and their effects in promoting growth of chili pepper (Capsicum annuum L. cv Jalapeño). Indian J. Microbiol. 2016, 56, 375-378. [CrossRef]

82. Gowtham, H.; Murali, M.; Singh, S.B.; Lakshmeesha, T.; Murthy, K.N.; Amruthesh, K.; Niranjana, S. Plant growth promoting rhizobacteria-Bacillus amyloliquefaciens improves plant growth and induces resistance in chilli against anthracnose disease. Biol. Control 2018, 126, 209-217. [CrossRef]

83. Sabaté, D.C.; Brandan, C.P.; Petroselli, G.; Erra-Balsells, R.; Audisio, M.C. Biocontrol of Sclerotinia sclerotiorum (Lib.) de Bary on common bean by native lipopeptide-producer Bacillus strains. Microbiol. Res. 2018, 211, 21-30. [CrossRef]

84. de Melo Pereira, G.V.; Magalhães, K.T.; Lorenzetii, E.R.; Souza, T.P.; Schwan, R.F. A multiphasic approach for the identification of endophytic bacterial in strawberry fruit and their potential for plant growth promotion. Microb. Ecol. 2012, 63, 405-417. [CrossRef]

85. Kumawat, K.C.; Sharma, P.; Sirari, A.; Singh, I.; Gill, B.S.; Singh, U.; Saharan, K. Synergism of Pseudomonas aeruginosa (LSE-2) nodule endophyte with Bradyrhizobium sp. (LSBR-3) for improving plant growth, nutrient acquisition and soil health in soybean. World J. Microbiol. Biotechnol. 2019, 35, 47. [CrossRef] [PubMed]

86. Sandhya, V. Endophytes from maize with plant growth promotion and biocontrol activity under drought stress. Russ. Agric. Sci. 2017, 43, 22-34. [CrossRef]

87. Rana, K.L.; Kour, D.; Kaur, T.; Sheikh, I.; Yadav, A.N.; Kumar, V.; Suman, A.; Dhaliwal, H.S. Endophytic Microbes from Diverse Wheat Genotypes and Their Potential Biotechnological Applications in Plant Growth Promotion and Nutrient Uptake. Proc. Natl. Acad. Sci. India Sect. B: Biol. Sci. 2020, 90, 969-979. [CrossRef]

88. Singh, D.; Geat, N.; Rajawat, M.V.S.; Mahajan, M.M.; Prasanna, R.; Singh, S.; Kaushik, R.; Singh, R.N.; Kumar, K.; Saxena, A.K. Deciphering the Mechanisms of Endophyte-Mediated Biofortification of Fe and Zn in Wheat. J. Plant Growth Regul. 2018, 37, 174-182. [CrossRef] 
89. Zhao, L.; Xu, Y.; Lai, X. Antagonistic endophytic bacteria associated with nodules of soybean (Glycine max L.) and plant growth-promoting properties. Braz. J. Microbiol. 2018, 49, 269-278. [CrossRef] [PubMed]

90. Spaink, H.P.; Kondorosi, A.; Hooykaas, P.J. The Rhizobiaceae: Molecular Biology of Model Plant-Associated Bacteria; Springer Science \& Business Media: Dordrecht, The Netherlands, 2012.

91. Shridhar, B.S. Nitrogen fixing microorganisms. Int. J. Microbiol. Res. (IJMR) 2012, 3, 46-52.

92. Ladha, J.K.; Reddy, P.M. Nitrogen fixation in rice systems: State of knowledge and future prospects. Plant Soil 2003, 252, 151-167. [CrossRef]

93. Bhattacharjee, R.B.; Singh, A.; Mukhopadhyay, S. Use of nitrogen-fixing bacteria as biofertiliser for non-legumes: Prospects and challenges. Appl. Microbiol. Biotechnol. 2008, 80, 199-209. [CrossRef]

94. Santi, C.; Bogusz, D.; Franche, C. Biological nitrogen fixation in non-legume plants. Ann. Bot. 2013, 111, 743-767. [CrossRef] [PubMed]

95. Triplett, E.W. Diazotrophic endophytes: Progress and prospects for nitrogen fixation in monocots. Plant Soil 1996, 186, 29-38. [CrossRef]

96. Hurek, T.; Reinhold-Hurek, B. Azoarcus sp. strain BH72 as a model for nitrogen-fixing grass endophytes. J. Biotechnol. 2003, 106, 169-178. [CrossRef] [PubMed]

97. Govindarajan, M.; Kwon, S.-W.; Weon, H.-Y. Isolation, molecular characterization and growth-promoting activities of endophytic sugarcane diazotroph Klebsiella sp. GR9. World J. Microbiol. Biotechnol. 2007, 23, 997-1006. [CrossRef]

98. Mirza, M.S.; Ahmad, W.; Latif, F.; Haurat, J.; Bally, R.; Normand, P.; Malik, K.A. Isolation, partial characterization, and the effect of plant growth-promoting bacteria (PGPB) on micro-propagated sugarcane in vitro. Plant Soil 2001, 237, 47-54. [CrossRef]

99. Luo, T.; Ouyang, X.; Yang, L.; Li, Y. Effect of nitrogen-fixing bacteria inoculation on biological nitrogen fixation in sugarcane by 15 N isotope dilution technique. J. Nucl. Agric. Sci. 2010, 24, 1026-1031.

100. Lin, L.; Li, Z.; Hu, C.; Zhang, X.; Chang, S.; Yang, L.; Li, Y.; An, Q. Plant growth-promoting nitrogen-fixing enterobacteria are in association with sugarcane plants growing in Guangxi, China. Microbes Environ. 2012, 27, 391-398. [CrossRef]

101. Wei, C.-Y.; Lin, L.; Luo, L.-J.; Xing, Y.-X.; Hu, C.-J.; Yang, L.-T.; Li, Y.-R.; An, Q. Endophytic nitrogen-fixing Klebsiella variicola strain DX120E promotes sugarcane growth. Biol. Fertil. Soils 2014, 50, 657-666. [CrossRef]

102. Xin, G.; Zhang, G.; Kang, J.W.; Staley, J.T.; Doty, S.L. A diazotrophic, indole-3-acetic acid-producing endophyte from wild cottonwood. Biol. Fertil. Soils 2009, 45, 669-674. [CrossRef]

103. Khan, Z.; Guelich, G.; Phan, H.; Redman, R.; Doty, S. Bacterial and yeast endophytes from poplar and willow promote growth in crop plants and grasses. ISRN Agron. 2012, 2012, 890280. [CrossRef]

104. Andrade, L.F. Analysis of the abilities of endophytic bacteria associated with banana tree roots to promote plant growth. J. Microbiol. 2014, 52, 27-34. [CrossRef]

105. Patel, J.K.; Archana, G. Diverse culturable diazotrophic endophytic bacteria from Poaceae plants show cross-colonization and plant growth promotion in wheat. Plant Soil 2017, 417, 99-116. [CrossRef]

106. Gupta, G.; Panwar, J.; Jha, P.N. Natural occurrence of Pseudomonas aeruginosa, a dominant cultivable diazotrophic endophytic bacterium colonizing Pennisetum glaucum (L.) R. Br. Appl. Soil Ecol. 2013, 64, 252-261. [CrossRef]

107. Yan, X.; Wang, Z.; Mei, Y.; Wang, L.; Wang, X.; Xu, Q.; Peng, S.; Zhou, Y.; Wei, C. Isolation, Diversity, and Growth-Promoting Activities of Endophytic Bacteria From Tea Cultivars of Zijuan and Yunkang-10. Front. Microbiol. 2018, 9. [CrossRef]

108. Rangjaroen, C.; Rerkasem, B.; Teaumroong, N.; Noisangiam, R.; Lumyong, S. Promoting plant growth in a commercial rice cultivar by endophytic diazotrophic bacteria isolated from rice landraces. Ann. Microbiol. 2015, 65, 253-266. [CrossRef]

109. Padda, K.P.; Puri, A.; Chanway, C. Endophytic nitrogen fixation-A possible 'hidden' source of nitrogen for lodgepole pine trees growing at unreclaimed gravel mining sites. FEMS Microbiol. Ecol. 2019, 95. [CrossRef]

110. Ji, S.H.; Gururani, M.A.; Chun, S.-C. Isolation and characterization of plant growth promoting endophytic diazotrophic bacteria from Korean rice cultivars. Microbiol. Res. 2014, 169, 83-98. [CrossRef] [PubMed]

111. Szilagyi-Zecchin, V.J.; Ikeda, A.C.; Hungria, M.; Adamoski, D.; Kava-Cordeiro, V.; Glienke, C.; Galli-Terasawa, L.V. Identification and characterization of endophytic bacteria from corn (Zea mays L.) roots with biotechnological potential in agriculture. $A M B$ Express 2014, 4, 26. [CrossRef] [PubMed]

112. Anand, R.; Chanway, C.P. nif gene sequence and arrangement in the endophytic diazotroph Paenibacillus polymyxa strain P2b-2R. Biol. Fertil. Soils 2013, 49, 965-970. [CrossRef]

113. Padda, K.P. Effect of GFP tagging of Paenibacillus polymyxa P2b-2R on its ability to promote growth of canola and tomato seedlings. Biol. Fertil. Soils 2016, 52, 377-387. [CrossRef]

114. Puri, A.; Padda, K.P.; Chanway, C.P. Evidence of endophytic diazotrophic bacteria in lodgepole pine and hybrid white spruce trees growing in soils with different nutrient statuses in the West Chilcotin region of British Columbia, Canada. For. Ecol. Manag. 2018, 430, 558-565. [CrossRef]

115. Doty, S.L.; Sher, A.W.; Fleck, N.D.; Khorasani, M.; Bumgarner, R.E.; Khan, Z.; Ko, A.W.K.; Kim, S.-H.; DeLuca, T.H. Variable Nitrogen Fixation in Wild Populus. PLoS ONE 2016, 11, e0155979. [CrossRef]

116. Araújo, A.E.d.S.; Baldani, V.L.D.; Galisa, P.d.S.; Pereira, J.A.; Baldani, J.I. Response of traditional upland rice varieties to inoculation with selected diazotrophic bacteria isolated from rice cropped at the Northeast region of Brazil. Appl. Soil Ecol. 2013, 64, 49-55. [CrossRef] 
117. Schultz, N.; Silva, J.A.d.; Sousa, J.S.; Monteiro, R.C.; Oliveira, R.P.; Chaves, V.A.; Pereira, W.; Silva, M.F.d.; Baldani, J.I.; Boddey, R.M.; et al. Inoculation of sugarcane with diazotrophic bacteria. Rev. Bras. De Ciência Do Solo 2014, 38, 407-414. [CrossRef]

118. Fang, K.; Bao, Z.-S.-N.; Chen, L.; Zhou, J.; Yang, Z.-P.; Dong, X.-F.; Zhang, H.-B. Growth-promoting characteristics of potential nitrogen-fixing bacteria in the root of an invasive plant Ageratina adenophora. Peer] 2019, 7, e7099. [CrossRef] [PubMed]

119. Gouda, S.; Kerry, R.G.; Das, G.; Paramithiotis, S.; Shin, H.-S.; Patra, J.K. Revitalization of plant growth promoting rhizobacteria for sustainable development in agriculture. Microbiol. Res. 2018, 206, 131-140. [CrossRef] [PubMed]

120. Rodríguez, H.; Fraga, R. Phosphate solubilizing bacteria and their role in plant growth promotion. Biotechnol. Adv. 1999, 17, 319-339. [CrossRef]

121. Van Der Heijden, M.G.A.; Bardgett, R.D.; Van Straalen, N.M. The unseen majority: Soil microbes as drivers of plant diversity and productivity in terrestrial ecosystems. Ecol. Lett. 2008, 11, 296-310. [CrossRef] [PubMed]

122. Singh, B.; Boukhris, I.; Pragya; Kumar, V.; Yadav, A.N.; Farhat-Khemakhem, A.; Kumar, A.; Singh, D.; Blibech, M.; Chouayekh, H.; et al. Contribution of microbial phytases to the improvement of plant growth and nutrition: A review. Pedosphere 2020, 30, 295-313. [CrossRef]

123. Delvasto, P.; Valverde, A.; Ballester, A.; Muñoz, J.A.; González, F.; Blázquez, M.L.; Igual, J.M.; García-Balboa, C. Diversity and activity of phosphate bioleaching bacteria from a high-phosphorus iron ore. Hydrometallurgy 2008, 92, 124-129. [CrossRef]

124. Yi, Y.; Huang, W.; Ge, Y. Exopolysaccharide: A novel important factor in the microbial dissolution of tricalcium phosphate. World J. Microbiol. Biotechnol. 2008, 24, 1059-1065. [CrossRef]

125. Vendan, R.T.; Yu, Y.; Lee, S.; Rhee, Y. Diversity of endophytic bacteria in ginseng and their potential for plant growth promotion. J. Microbiol. 2010, 48, 559-565. [CrossRef] [PubMed]

126. Palaniappan, P.; Chauhan, P.S.; Saravanan, V.S.; Anandham, R.; Sa, T. Isolation and characterization of plant growth promoting endophytic bacterial isolates from root nodule of Lespedeza sp. Biol. Fertil. Soils 2010, 46, 807-816. [CrossRef]

127. Dias, A.C.F.; Costa, F.E.C.; Andreote, F.D.; Lacava, P.T.; Teixeira, M.A.; Assumpção, L.C.; Araújo, W.L.; Azevedo, J.L.; Melo, I.S. Isolation of micropropagated strawberry endophytic bacteria and assessment of their potential for plant growth promotion. World J. Microbiol. Biotechnol. 2009, 25, 189-195. [CrossRef]

128. Puente, M.E.; Li, C.Y.; Bashan, Y. Endophytic bacteria in cacti seeds can improve the development of cactus seedlings. Environ. Exp. Bot. 2009, 66, 402-408. [CrossRef]

129. Verma, P.; Yadav, A.N.; Khannam, K.S.; Panjiar, N.; Kumar, S.; Saxena, A.K.; Suman, A. Assessment of genetic diversity and plant growth promoting attributes of psychrotolerant bacteria allied with wheat (Triticum aestivum) from the northern hills zone of India. Ann. Microbiol. 2015, 65, 1885-1899. [CrossRef]

130. Taurian, T.; Anzuay, M.S.; Angelini, J.G.; Tonelli, M.L.; Ludueña, L.; Pena, D.; Ibáñez, F.; Fabra, A. Phosphate-solubilizing peanut associated bacteria: Screening for plant growth-promoting activities. Plant Soil 2010, 329, 421-431. [CrossRef]

131. Kurek, E.; Ozimek, E.; Sobiczewski, P.; Słomka, A.; Jaroszuk-Ściseł, J. Effect of Pseudomonas luteola on mobilization of phosphorus and growth of young apple trees (Ligol)_Pot experiment. Sci. Hortic. 2013, 164, 270-276. [CrossRef]

132. Pereira, S.I.A.; Castro, P.M.L. Phosphate-solubilizing rhizobacteria enhance Zea mays growth in agricultural P-deficient soils. Ecol. Eng. 2014, 73, 526-535. [CrossRef]

133. Otieno, N.; Lally, R.; Kiwanuka, S.; Lloyd, A.; Ryan, D.; Germaine, K.; Dowling, D. Plant growth promotion induced by phosphate solubilizing endophytic Pseudomonas isolates. Front. Microbiol. 2015, 6. [CrossRef]

134. Joe, M.M.; Devaraj, S.; Benson, A.; Sa, T. Isolation of phosphate solubilizing endophytic bacteria from Phyllanthus amarus Schum \& Thonn: Evaluation of plant growth promotion and antioxidant activity under salt stress. J. Appl. Res. Med. Aromat. Plants 2016, 3, 71-77. [CrossRef]

135. Chen, Y.; Fan, J.-B.; Du, L.; Xu, H.; Zhang, Q.-H.; He, Y.-Q. The application of phosphate solubilizing endophyte Pantoea dispersa triggers the microbial community in red acidic soil. Appl. Soil Ecol. 2014, 84, 235-244. [CrossRef]

136. Castro, R.A.; Dourado, M.N.; Almeida, J.R.d.; Lacava, P.T.; Nave, A.; Melo, I.S.d.; Azevedo, J.L.d.; Quecine, M.C. Mangrove endophyte promotes reforestation tree (Acacia polyphylla) growth. brazilian journal of microbiology 2018, 49, 59-66. [CrossRef]

137. Ma, Y.; Rajkumar, M.; Zhang, C.; Freitas, H. Beneficial role of bacterial endophytes in heavy metal phytoremediation. J. Environ. Manag. 2016, 174, 14-25. [CrossRef] [PubMed]

138. Saha, M.; Sarkar, S.; Sarkar, B.; Sharma, B.K.; Bhattacharjee, S.; Tribedi, P. Microbial siderophores and their potential applications: A review. Environ. Sci. Pollut. Res. 2016, 23, 3984-3999. [CrossRef] [PubMed]

139. Neubauer, U.; Furrer, G.; Kayser, A.; Schulin, R. Siderophores, NTA, and Citrate: Potential Soil Amendments to Enhance Heavy Metal Mobility in Phytoremediation. Int. J. Phytoremediation 2000, 2, 353-368. [CrossRef]

140. Senthilkumar, M.; Swarnalakshmi, K.; Govindasamy, V.; Lee, Y.K.; Annapurna, K. Biocontrol Potential of Soybean Bacterial Endophytes Against Charcoal Rot Fungus, Rhizoctonia bataticola. Curr. Microbiol. 2008, 58, 288. [CrossRef] [PubMed]

141. Han, S.; Zhang, S.; Lin, T.; Gong, M. Screening for siderophore-producing endophytic bacteria against Fusarium oxysporum. Agric. Sci. Technol. Hunan 2011, 12, 994-996.

142. Lacava, P.T.; Silva-Stenico, M.E.; Araújo, W.L.; Simionato, A.V.C.; Carrilho, E.; Tsai, S.M.; Azevedo, J.L. Detection of siderophores in endophytic bacteria Methylobacterium spp. associated with Xylella fastidiosa subsp. pauca. Pesqui. Agropecuária Bras. 2008, 43, 521-528. [CrossRef] 
143. Pandey, P.; Irulappan, V.; Bagavathiannan, M.V.; Senthil-Kumar, M. Impact of Combined Abiotic and Biotic Stresses on Plant Growth and Avenues for Crop Improvement by Exploiting Physio-morphological Traits. Front. Plant Sci. 2017, 8, 537. [CrossRef] [PubMed]

144. Suzuki, N.; Rivero, R.M.; Shulaev, V.; Blumwald, E.; Mittler, R. Abiotic and biotic stress combinations. New Phytol. 2014, 203, 32-43. [CrossRef]

145. Kumar, A.; Verma, J.P. Does plant-Microbe interaction confer stress tolerance in plants: A review? Microbiol. Res. 2018, 207, 41-52. [CrossRef]

146. Meena, K.K.; Sorty, A.M.; Bitla, U.M.; Choudhary, K.; Gupta, P.; Pareek, A.; Singh, D.P.; Prabha, R.; Sahu, P.K.; Gupta, V.K.; et al. Abiotic Stress Responses and Microbe-Mediated Mitigation in Plants: The Omics Strategies. Front. Plant Sci. 2017, 8, 172. [CrossRef] [PubMed]

147. Lata, R.; Chowdhury, S.; Gond, S.K.; White Jr, J.F. Induction of abiotic stress tolerance in plants by endophytic microbes. Lett. Appl. Microbiol. 2018, 66, 268-276. [CrossRef]

148. Ullah, A.; Nisar, M.; Ali, H.; Hazrat, A.; Hayat, K.; Keerio, A.A.; Ihsan, M.; Laiq, M.; Ullah, S.; Fahad, S.; et al. Drought tolerance improvement in plants: An endophytic bacterial approach. Appl. Microbiol. Biotechnol. 2019, 103, 7385-7397. [CrossRef] [PubMed]

149. Razzaghi Komaresofla, B.; Alikhani, H.A.; Etesami, H.; Khoshkholgh-Sima, N.A. Improved growth and salinity tolerance of the halophyte Salicornia sp. by co-inoculation with endophytic and rhizosphere bacteria. Appl. Soil Ecol. 2019, 138, 160-170. [CrossRef]

150. Pandey, P.K.; Samanta, R.; Yadav, R.N.S. Inside the plant: Addressing bacterial endophytes in biotic stress alleviation. Arch. Microbiol. 2019, 201, 415-429. [CrossRef]

151. Khan, N.A.; Khan, M.I.R. The ethylene: From senescence hormone to key player in plant metabolism. J. Plant Biochem. Physiol. 2014. [CrossRef]

152. Tiwari, G.; Duraivadivel, P.; Sharma, S.; Hariprasad, P. 1-Aminocyclopropane-1-carboxylic acid deaminase producing beneficial rhizobacteria ameliorate the biomass characters of Panicum maximum Jacq. by mitigating drought and salt stress. Sci. Rep. 2018, 8, 17513. [CrossRef]

153. Grobelak, A.; Kokot, P.; Świątek, J.; Jaskulak, M.; Rorat, A. Bacterial ACC Deaminase Activity in Promoting Plant Growth on Areas Contaminated with Heavy Metals. J. Ecol. Eng. 2018, 19, 150-157. [CrossRef]

154. Afridi, M.S.; Mahmood, T.; Salam, A.; Mukhtar, T.; Mehmood, S.; Ali, J.; Khatoon, Z.; Bibi, M.; Javed, M.T.; Sultan, T. Induction of tolerance to salinity in wheat genotypes by plant growth promoting endophytes: Involvement of ACC deaminase and antioxidant enzymes. Plant Physiol. Biochem. 2019, 139, 569-577. [CrossRef]

155. Glick, B.R. Bacteria with ACC deaminase can promote plant growth and help to feed the world. Microbiol. Res. 2014, 169, 30-39. [CrossRef]

156. Ali, S.; Charles, T.C.; Glick, B.R. Amelioration of high salinity stress damage by plant growth-promoting bacterial endophytes that contain ACC deaminase. Plant Physiol. Biochem. 2014, 80, 160-167. [CrossRef] [PubMed]

157. Złoch, M.; Thiem, D.; Gadzała-Kopciuch, R.; Hrynkiewicz, K. Synthesis of siderophores by plant-associated metallotolerant bacteria under exposure to $\mathrm{Cd}^{2+}$. Chemosphere 2016, 156, 312-325. [CrossRef] [PubMed]

158. Farooq, M.; Wahid, A.; Kobayashi, N.; Fujita, D.; Basra, S.M.A. Plant Drought Stress: Effects, Mechanisms and Management. In Sustainable Agriculture; Lichtfouse, E., Navarrete, M., Debaeke, P., Véronique, S., Alberola, C., Eds.; Springer: Dordrecht, The Netherlands, 2009; pp. 153-188.

159. Barka, E.A.; Nowak, J.; Clément, C. Enhancement of chilling resistance of inoculated grapevine plantlets with a plant growthpromoting rhizobacterium, Burkholderia phytofirmans strain PsJN. Appl. Environ. Microbiol. 2006, 72, 7246-7252. [CrossRef]

160. Fernandez, O.; Theocharis, A.; Bordiec, S.; Feil, R.; Jacquens, L.; Clément, C.; Fontaine, F.; Barka, E.A. Burkholderia phytofirmans PsJN Acclimates Grapevine to Cold by Modulating Carbohydrate Metabolism. Mol. Plant-Microbe Interact. 2012, 25, 496-504. [CrossRef] [PubMed]

161. Naveed, M.; Mitter, B.; Reichenauer, T.G.; Wieczorek, K.; Sessitsch, A. Increased drought stress resilience of maize through endophytic colonization by Burkholderia phytofirmans PsJN and Enterobacter sp. FD17. Environ. Exp. Bot. 2014, 97, 30-39. [CrossRef]

162. Vargas, L.; Santa Brígida, A.B.; Mota Filho, J.P.; de Carvalho, T.G.; Rojas, C.A.; Vaneechoutte, D.; Van Bel, M.; Farrinelli, L.; Ferreira, P.C.G.; Vandepoele, K.; et al. Drought tolerance conferred to sugarcane by association with Gluconacetobacter diazotrophicus: A transcriptomic view of hormone pathways. PLoS ONE 2014, 9, e114744. [CrossRef] [PubMed]

163. Timmusk, S.; El-Daim, I.A.A.; Copolovici, L.; Tanilas, T.; Kännaste, A.; Behers, L.; Nevo, E.; Seisenbaeva, G.; Stenström, E.; Niinemets, Ü. Drought-tolerance of wheat improved by rhizosphere bacteria from harsh environments: Enhanced biomass production and reduced emissions of stress volatiles. PLoS ONE 2014, 9, e96086. [CrossRef]

164. Jiao, J.; Ma, Y.; Chen, S.; Liu, C.; Song, Y.; Qin, Y.; Yuan, C.; Liu, Y. Melatonin-Producing Endophytic Bacteria from Grapevine Roots Promote the Abiotic Stress-Induced Production of Endogenous Melatonin in Their Hosts. Front. Plant Sci. 2016, 7, 1387. [CrossRef] [PubMed]

165. Chen, C.; Xin, K.; Liu, H.; Cheng, J.; Shen, X.; Wang, Y.; Zhang, L. Pantoea alhagi, a novel endophytic bacterium with ability to improve growth and drought tolerance in wheat. Sci. Rep. 2017, 7, 41564. [CrossRef] 
166. Vigani, G.; Rolli, E.; Marasco, R.; Dell’Orto, M.; Michoud, G.; Soussi, A.; Raddadi, N.; Borin, S.; Sorlini, C.; Zocchi, G.; et al. Root bacterial endophytes confer drought resistance and enhance expression and activity of a vacuolar H+-pumping pyrophosphatase in pepper plants. Environ. Microbiol. 2019, 21, 3212-3228. [CrossRef] [PubMed]

167. Xie, Z.; Chu, Y.; Zhang, W.; Lang, D.; Zhang, X. Bacillus pumilus alleviates drought stress and increases metabolite accumulation in Glycyrrhiza uralensis Fisch. Environ. Exp. Bot. 2019, 158, 99-106. [CrossRef]

168. Jayakumar, A.; Padmakumar, P.; Nair, I.C.; Radhakrishnan, E.K. Drought tolerant bacterial endophytes with potential plant probiotic effects from Ananas comosus. Biologia 2020, 75, 1769-1778. [CrossRef]

169. Naya, L.; Ladrera, R.; Ramos, J.; González, E.M.; Arrese-Igor, C.; Minchin, F.R.; Becana, M. The Response of Carbon Metabolism and Antioxidant Defenses of Alfalfa Nodules to Drought Stress and to the Subsequent Recovery of Plants. Plant Physiol. 2007, 144, 1104. [CrossRef] [PubMed]

170. Yachana, J.; Subramanian, R.B.; Suchita, P. Combination of endophytic and rhizospheric plant growth promoting rhizobacteria in Oryza sativa shows higher accumulation of osmoprotectant against saline stress. Acta Physiol. Plant. 2011, 33, 797-802. [CrossRef]

171. Han, Y.; Wang, R.; Yang, Z.; Zhan, Y.; Ma, Y.; Ping, S.; Zhang, L.; Lin, M.; Yan, Y. 1-Aminocyclopropane-1-Carboxylate Deaminase from Pseudomonas stutzeri A1501 Facilitates the Growth of Rice in the Presence of Salt or Heavy Metals. J. Microbiol. Biotechnol. 2015, 25, 1119-1128. [CrossRef] [PubMed]

172. Sorty, A.M.; Meena, K.K.; Choudhary, K.; Bitla, U.M.; Minhas, P.S.; Krishnani, K.K. Effect of Plant Growth Promoting Bacteria Associated with Halophytic Weed (Psoralea corylifolia L) on Germination and Seedling Growth of Wheat Under Saline Conditions. Appl. Biochem. Biotechnol. 2016, 180, 872-882. [CrossRef]

173. Ma, Y.; Rajkumar, M.; Freitas, H. Inoculation of plant growth promoting bacterium Achromobacter xylosoxidans strain Ax10 for the improvement of copper phytoextraction by Brassica juncea. J. Environ. Manag. 2009, 90, 831-837. [CrossRef]

174. Zhang, Y.-f.; He, L.-y.; Chen, Z.-j.; Wang, Q.-y.; Qian, M.; Sheng, X.-f. Characterization of ACC deaminase-producing endophytic bacteria isolated from copper-tolerant plants and their potential in promoting the growth and copper accumulation of Brassica napus. Chemosphere 2011, 83, 57-62. [CrossRef] [PubMed]

175. Abd_Allah, E.F.; Alqarawi, A.A.; Hashem, A.; Radhakrishnan, R.; Al-Huqail, A.A.; Al-Otibi, F.O.N.; Malik, J.A.; Alharbi, R.I.; Egamberdieva, D. Endophytic bacterium Bacillus subtilis (BERA 71) improves salt tolerance in chickpea plants by regulating the plant defense mechanisms. J. Plant Interact. 2018, 13, 37-44. [CrossRef]

176. Khan, M.A.; Asaf, S.; Khan, A.L.; Adhikari, A.; Jan, R.; Ali, S.; Imran, M.; Kim, K.M.; Lee, I.J. Plant growth-promoting endophytic bacteria augment growth and salinity tolerance in rice plants. Plant Biol. 2020, 22, 850-862. [CrossRef] [PubMed]

177. Abdelshafy Mohamad, O.A.; Ma, J.-B.; Liu, Y.-H.; Zhang, D.; Hua, S.; Bhute, S.; Hedlund, B.P.; Li, W.-J.; Li, L. Beneficial Endophytic Bacterial Populations Associated With Medicinal Plant Thymus vulgaris Alleviate Salt Stress and Confer Resistance to Fusarium oxysporum. Front. Plant Sci. 2020, 11, 47. [CrossRef]

178. Fan, M.; Liu, Z.; Nan, L.; Wang, E.; Chen, W.; Lin, Y.; Wei, G. Isolation, characterization, and selection of heavy metal-resistant and plant growth-promoting endophytic bacteria from root nodules of Robinia pseudoacacia in a Pb/Zn mining area. Microbiol. Res. 2018, 217, 51-59. [CrossRef]

179. Jan, R.; Khan, M.A.; Asaf, S.; Lubna; Lee, I.-J.; Kim, K.M. Metal Resistant Endophytic Bacteria Reduces Cadmium, Nickel Toxicity, and Enhances Expression of Metal Stress Related Genes with Improved Growth of Oryza Sativa, via Regulating Its Antioxidant Machinery and Endogenous Hormones. Plants 2019, 8, 363. [CrossRef]

180. Chen, J.; Li, N.; Han, S.; Sun, Y.; Wang, L.; Qu, Z.; Dai, M.; Zhao, G. Characterization and bioremediation potential of nickelresistant endophytic bacteria isolated from the wetland plant Tamarix chinensis. FEMS Microbiol. Lett. 2020, 367. [CrossRef]

181. Feng, N.-X.; Yu, J.; Zhao, H.-M.; Cheng, Y.-T.; Mo, C.-H.; Cai, Q.-Y.; Li, Y.-W.; Li, H.; Wong, M.-H. Efficient phytoremediation of organic contaminants in soils using plant-endophyte partnerships. Sci. Total Environ. 2017, 583, 352-368. [CrossRef] [PubMed]

182. Phillips, L.A.; Germida, J.J.; Farrell, R.E.; Greer, C.W. Hydrocarbon degradation potential and activity of endophytic bacteria associated with prairie plants. Soil Biol. Biochem. 2008, 40, 3054-3064. [CrossRef]

183. Van Aken, B.; Yoon, J.M.; Schnoor, J.L. Biodegradation of nitro-substituted explosives 2,4,6-trinitrotoluene, hexahydro-1,3,5trinitro-1,3,5-triazine, and octahydro-1,3,5,7-tetranitro-1,3,5-tetrazocine by a phytosymbiotic Methylobacterium sp. associated with poplar tissues (Populus deltoides x nigra DN34). Appl. Environ. Microbiol. 2004, 70, 508-517. [CrossRef]

184. Germaine, K.J.; Liu, X.; Cabellos, G.G.; Hogan, J.P.; Ryan, D.; Dowling, D.N. Bacterial endophyte-enhanced phytoremediation of the organochlorine herbicide 2,4-dichlorophenoxyacetic acid. FEMS Microbiol. Ecol. 2006, 57, 302-310. [CrossRef]

185. Ashraf, S.; Afzal, M.; Naveed, M.; Shahid, M.; Ahmad Zahir, Z. Endophytic bacteria enhance remediation of tannery effluent in constructed wetlands vegetated with Leptochloa fusca. Int. J. Phytoremediation 2018, 20, 121-128. [CrossRef]

186. Ahsan, M.T.; Najam-ul-haq, M.; Idrees, M.; Ullah, I.; Afzal, M. Bacterial endophytes enhance phytostabilization in soils contaminated with uranium and lead. Int. J. Phytoremediation 2017, 19, 937-946. [CrossRef]

187. Eevers, N.; Hawthorne, J.R.; White, J.C.; Vangronsveld, J.; Weyens, N. Endophyte-enhanced phytoremediation of DDEcontaminated using Cucurbita pepo: A field trial. Int. J. Phytoremediation 2018, 20, 301-310. [CrossRef]

188. Mitter, E.K.; Kataoka, R.; de Freitas, J.R.; Germida, J.J. Potential use of endophytic root bacteria and host plants to degrade hydrocarbons. Int. J. Phytoremediation 2019, 21, 928-938. [CrossRef]

189. Wu, T.; Xu, J.; Liu, J.; Guo, W.-H.; Li, X.-B.; Xia, J.-B.; Xie, W.-J.; Yao, Z.-G.; Zhang, Y.-M.; Wang, R.-Q. Characterization and Initial Application of Endophytic Bacillus safensis Strain ZY16 for Improving Phytoremediation of Oil-Contaminated Saline Soils. Front. Microbiol. 2019, 10, 991. [CrossRef] [PubMed] 
190. Latha, P.; Karthikeyan, M.; Rajeswari, E. Endophytic Bacteria: Prospects and Applications for the Plant Disease Management. In Plant Health Under Biotic Stress: Volume 2: Microbial Interactions; Ansari, R.A., Mahmood, I., Eds.; Springer: Singapore, 2019; pp. $1-50$.

191. Lashin, I.; Fouda, A.; Gobouri, A.A.; Azab, E.; Mohammedsaleh, Z.M.; Makharita, R.R. Antimicrobial and In Vitro Cytotoxic Efficacy of Biogenic Silver Nanoparticles (Ag-NPs) Fabricated by Callus Extract of Solanum incanum L. Biomolecules 2021, 11, 341 [CrossRef]

192. Ongena, M.; Jacques, P. Bacillus lipopeptides: Versatile weapons for plant disease biocontrol. Trends Microbiol. 2008, 16, 115-125. [CrossRef] [PubMed]

193. Fouda, A.; Hassan, S.E.D.; Eid, A.M.; El-Din Ewais, E. The Interaction Between Plants and Bacterial Endophytes Under Salinity Stress. In Endophytes and Secondary Metabolites; Jha, S., Ed.; Springer International Publishing: Cham, Switzerland, 2018; pp. 1-17.

194. Blumenstein, K.; Albrectsen, B.R.; Martín, J.A.; Hultberg, M.; Sieber, T.N.; Helander, M.; Witzell, J. Nutritional niche overlap potentiates the use of endophytes in biocontrol of a tree disease. BioControl 2015, 60, 655-667. [CrossRef]

195. Höfte, M. Classes of Microbial Siderophores; Academic Press: San Diego, CA, USA, 1993.

196. Cordova-Albores, L.C.; Zapotitla, E.S.; Ríos, M.Y.; Barrera-Necha, L.L.; Hernández-López, M.; Bautista-Baños, S. Microscopic study of the morphology and metabolic activity of Fusarium oxysporum $\mathrm{f}$. sp. gladioli treated with Jatropha curcas oil and derivatives. J. Microsc. Ultrastruct. 2016, 4, 28-35. [CrossRef] [PubMed]

197. Torres, R.; Solsona, C.; Viñas, I.; Usall, J.; Plaza, P.; Teixidó, N. Optimization of packaging and storage conditions of a freeze-dried Pantoea agglomerans formulation for controlling postharvest diseases in fruit. J. Appl. Microbiol. 2014, 117, 173-184. [CrossRef]

198. Fialho, M.B.; Moraes, M.H.D.d.; Tremocoldi, A.R.; Pascholati, S.F. Potential of antimicrobial volatile organic compounds to control Sclerotinia sclerotiorum in bean seeds. Pesqui. Agropecuária Bras. 2011, 46, 137-142. [CrossRef]

199. Jasim, B.; Sreelakshmi, K.S.; Mathew, J.; Radhakrishnan, E.K. Surfactin, Iturin, and Fengycin Biosynthesis by Endophytic Bacillus sp. from Bacopa monnieri. Microb. Ecol. 2016, 72, 106-119. [CrossRef] [PubMed]

200. Chowdhury, F.T.; Islam, M.R.; Islam, M.R.; Khan, H. Diversity of Plant Endophytic Volatile Organic Compound (VOC) and Their Potential Applications. In Endophytes and Secondary Metabolites; Jha, S., Ed.; Springer International Publishing: Cham, Switzerland, 2018; pp. 1-27.

201. Spadaro, D.; Droby, S. Development of biocontrol products for postharvest diseases of fruit: The importance of elucidating the mechanisms of action of yeast antagonists. Trends Food Sci. Technol. 2016, 47, 39-49. [CrossRef]

202. Piromyou, P.; Songwattana, P.; Greetatorn, T.; Okubo, T.; Chiba Kakizaki, K.; Prakamhang, J.; Tittabutr, P.; Boonkerd, N.; Teaumroong, N.; Minamisawa, K. The Type III Secretion System (T3SS) is a Determinant for Rice-Endophyte Colonization by Non-Photosynthetic Bradyrhizobium. Microbes Environ. 2015, advpub. [CrossRef]

203. Backman, P.A.; Sikora, R.A. Endophytes: An emerging tool for biological control. Biol. Control 2008, 46, 1-3. [CrossRef]

204. Miliute, I.; Buzaite, O.; Baniulis, D.; Stanys, V. Bacterial endophytes in agricultural crops and their role in stress tolerance: A review. Žemdirbystè (Agric.) 2015, 102, 465-478. [CrossRef]

205. Rashid, M.H.-O.; Khan, A.; Hossain, M.T.; Chung, Y.R. Induction of Systemic Resistance against Aphids by Endophytic Bacillus velezensis YC7010 via Expressing PHYTOALEXIN DEFICIENT4 in Arabidopsis. Front. Plant Sci. 2017, 8, 211. [CrossRef]

206. Lugtenberg, B.; Kamilova, F. Plant-Growth-Promoting Rhizobacteria. Annu. Rev. Microbiol. 2009, 63, 541-556. [CrossRef]

207. Maloy, O.C.; Murray, T.D. Encyclopedia of Plant Pathology; Wiley: New York, NY, USA, 2001.

208. Uroz, S.; D'Angelo-Picard, C.; Carlier, A.; Elasri, M.; Sicot, C.; Petit, A.; Oger, P.; Faure, D.; Dessaux, Y. Novel bacteria degrading $\mathrm{N}$-acylhomoserine lactones and their use as quenchers of quorum-sensing-regulated functions of plant-pathogenic bacteria. Microbiol. (Read. Engl.) 2003, 149, 1981-1989. [CrossRef]

209. Gao, Z.; Zhang, B.; Liu, H.; Han, J.; Zhang, Y. Identification of endophytic Bacillus velezensis ZSY-1 strain and antifungal activity of its volatile compounds against Alternaria solani and Botrytis cinerea. Biol. Control 2017, 105, 27-39. [CrossRef]

210. Perneel, M.; D’Hondt, L.; De Maeyer, K.; Adiobo, A.; Rabaey, K.; Höfte, M. Phenazines and biosurfactants interact in the biological control of soil-borne diseases caused by Pythium spp. Environ. Microbiol. 2008, 10, 778-788. [CrossRef]

211. Zeriouh, H.; Romero, D.; García-Gutiérrez, L.; Cazorla, F.M.; de Vicente, A.; Pérez-García, A. The Iturin-like Lipopeptides Are Essential Components in the Biological Control Arsenal of Bacillus subtilis Against Bacterial Diseases of Cucurbits. Mol. Plant-Microbe Interact. 2011, 24, 1540-1552. [CrossRef] [PubMed]

212. Tabbene, O.; Ben Slimene, I.; Bouabdallah, F.; Mangoni, M.-L.; Urdaci, M.-C.; Limam, F. Production of Anti-Methicillin-Resistant Staphylococcus Activity from Bacillus subtilis sp. Strain B38 Newly Isolated from Soil. Appl. Biochem. Biotechnol. 2009, 157, 407-419. [CrossRef] [PubMed]

213. Pliego, C.; Kamilova, F.; Lugtenberg, B. Plant Growth-Promoting Bacteria: Fundamentals and Exploitation. In Bacteria in Agrobiology: Crop Ecosystems; Maheshwari, D.K., Ed.; Springer: Berlin/Heidelberg, Germany, 2011; pp. 295-343.

214. Silva, H.S.A.; Romeiro, R.d.S.; Macagnan, D.; Halfeld-Vieira, B.d.A.; Pereira, M.C.B.; Mounteer, A. Rhizobacterial induction of systemic resistance in tomato plants: Non-specific protection and increase in enzyme activities. Biol. Control 2004, 29, 288-295. [CrossRef]

215. Schuhegger, R.; Ihring, A.; Gantner, S.; Bahnweg, G.; Knappe, C.; Vogg, G.; Hutzler, P.; Schmid, M.; Van Breusegem, F.; Eberl, L.E.O.; et al. Induction of systemic resistance in tomato by $\mathrm{N}$-acyl-L-homoserine lactone-producing rhizosphere bacteria. Plant Cell Environ. 2006, 29, 909-918. [CrossRef] [PubMed] 
216. Audenaert, K.; Pattery, T.; Cornelis, P.; Höfte, M. Induction of Systemic Resistance to Botrytis cinerea in Tomato by Pseudomonas aeruginosa 7NSK2: Role of Salicylic Acid, Pyochelin, and Pyocyanin. Mol. Plant-Microbe Interact. 2002, 15, 1147-1156. [CrossRef]

217. Newman, D.J.; Cragg, G.M. Chapter 1 Natural Products as Drugs and Leads to Drugs: The Historical Perspective. In Natural Product Chemistry for Drug Discovery; The Royal Society of Chemistry: London, UK, 2009; pp. 3-27.

218. Kapoor, N.; Jamwal, V.L.; Gandhi, S.G. Endophytes as a Source of High-Value, Bioactive Metabolites; Springer: Berlin, Germany, 2018. [CrossRef]

219. Ek-Ramos, M.J.; Gomez-Flores, R.; Orozco-Flores, A.A.; Rodríguez-Padilla, C.; González-Ochoa, G.; Tamez-Guerra, P. Bioactive Products From Plant-Endophytic Gram-Positive Bacteria. Front. Microbiol. 2019, 10, 463. [CrossRef] [PubMed]

220. Alvin, A.; Miller, K.I.; Neilan, B.A. Exploring the potential of endophytes from medicinal plants as sources of antimycobacterial compounds. Microbiol. Res. 2014, 169, 483-495. [CrossRef]

221. Monowar, T.; Rahman, M.S.; Bhore, S.J.; Raju, G.; Sathasivam, K.V. Secondary Metabolites Profiling of Acinetobacter baumannii Associated with Chili (Capsicum annuum L.) Leaves and Concentration Dependent Antioxidant and Prooxidant Properties. Biomed Res. Int. 2019, 2019, 6951927. [CrossRef] [PubMed]

222. Abdalla, M.A.; Matasyoh, J.C. Endophytes as producers of peptides: An overview about the recently discovered peptides from endophytic microbes. Nat. Prod. Bioprospecting 2014, 4, 257-270. [CrossRef]

223. Singh, M.; Kumar, A.; Singh, R.; Pandey, K.D. Endophytic bacteria: A new source of bioactive compounds. 3 Biotech 2017, 7, 315. [CrossRef] [PubMed]

224. Hashem, A.; Abd_Allah, E.F.; Alqarawi, A.A.; Al-Huqail, A.A.; Shah, M.A. Induction of Osmoregulation and Modulation of Salt Stress in Acacia gerrardii Benth. by Arbuscular Mycorrhizal Fungi and Bacillus subtilis (BERA 71). Biomed Res. Int. 2016, 2016, 6294098. [CrossRef]

225. Mitsuhashi, S. Current topics in the biotechnological production of essential amino acids, functional amino acids, and dipeptides. Curr. Opin. Biotechnol. 2014, 26, 38-44. [CrossRef] [PubMed]

226. Geddes, C.C.; Nieves, I.U.; Ingram, L.O. Advances in ethanol production. Curr. Opin. Biotechnol. 2011, 22, 312-319. [CrossRef] [PubMed]

227. Soliman, A.M.; Abdel-Latif, W.; Shehata, I.H.; Fouda, A.; Abdo, A.M.; Ahmed, Y.M. Green Approach to Overcome the Resistance Pattern of Candida spp. Using Biosynthesized Silver Nanoparticles Fabricated by Penicillium chrysogenum F9. Biological Trace Element Research 2021, 199, 800-811. [CrossRef] [PubMed]

228. Shaligram, N.S.; Singhal, R.S. Surfactin-A review on biosynthesis, fermentation, purification and applications. Food Technol. Biotechnol. 2010, 48, 119-134.

229. Yoon, Y.J.; Kim, E.S.; Hwang, Y.S.; Choi, C.Y. Avermectin: Biochemical and molecular basis of its biosynthesis and regulation. Appl. Microbiol. Biotechnol. 2004, 63, 626-634. [CrossRef]

230. Ntabo, R.M.; Nyamache, A.K.; Lwande, W.; Kabii, J.; Nonoh, J. Enzymatic Activity of Endophytic Bacterial Isolates from Selected Mangrove Plants in Kenya. Open Microbiol. J. 2018, 12, 354-363. [CrossRef]

231. Wu, T.; Xu, J.; Xie, W.; Yao, Z.; Yang, H.; Sun, C.; Li, X. Pseudomonas aeruginosa L10: A Hydrocarbon-Degrading, BiosurfactantProducing, and Plant-Growth-Promoting Endophytic Bacterium Isolated From a Reed (Phragmites australis). Front. Microbiol. 2018, 9, 1087. [CrossRef]

232. Baker, S.; Sahana, S.; Rakshith, D.; Kavitha, H.; Kavitha, K.; Satish, S. Biodecaffeination by endophytic Pseudomonas sp. isolated from Coffee arabica L. J. Pharm. Res. 2012, 5, 3654-3657.

233. Mohamed, A.A.; Fouda, A.; Abdel-Rahman, M.A.; Hassan, S.E.D.; El-Gamal, M.S.; Salem, S.S.; Shaheen, T.I. Fungal strain impacts the shape, bioactivity and multifunctional properties of green synthesized zinc oxide nanoparticles. Biocatal. Agric. Biotechnol. 2019, 19. [CrossRef]

234. Aref, M.S.; Salem, S.S. Bio-callus synthesis of silver nanoparticles, characterization, and antibacterial activities via Cinnamomum camphora callus culture. Biocatal. Agric. Biotechnol. 2020, 27. [CrossRef]

235. Shaheen, T.I.; Fouda, A.; Salem, S.S. Integration of Cotton Fabrics with Biosynthesized CuO Nanoparticles for Bactericidal Activity in the Terms of Their Cytotoxicity Assessment. Ind. Eng. Chem. Res. 2021, 60, 1553-1563. [CrossRef]

236. Fouda, A.; Abdel-Maksoud, G.; Abdel-Rahman, M.A.; Eid, A.M.; Barghoth, M.G.; El-Sadany, M.A.H. Monitoring the effect of biosynthesized nanoparticles against biodeterioration of cellulose-based materials by Aspergillus niger. Cellulose 2019, 26, 6583-6597. [CrossRef]

237. Fouda, A.; Abdel-Maksoud, G.; Abdel-Rahman, M.A.; Salem, S.S.; Hassan, S.E.-D.; El-Sadany, M.A.-H. Eco-friendly approach utilizing green synthesized nanoparticles for paper conservation against microbes involved in biodeterioration of archaeological manuscript. Int. Biodeterior. Biodegrad. 2019, 142, 160-169. [CrossRef]

238. Fouda, A.; Hassan, S.E.-D.; Saied, E.; Azab, M.S. An eco-friendly approach to textile and tannery wastewater treatment using maghemite nanoparticles $\left(\gamma-\mathrm{Fe}_{2} \mathrm{O}_{3}-\mathrm{NPs}\right)$ fabricated by Penicillium expansum strain (K-w). J. Environ. Chem. Eng. 2021, 9, 104693. [CrossRef]

239. Fouda, A.; Hassan, S.E.-D.; Saied, E.; Hamza, M.F. Photocatalytic degradation of real textile and tannery effluent using biosynthesized magnesium oxide nanoparticles (MgO-NPs), heavy metal adsorption, phytotoxicity, and antimicrobial activity. J. Environ. Chem. Eng. 2021, 9, 105346. [CrossRef]

240. Salem, S.S.; Fouda, A. Green Synthesis of Metallic Nanoparticles and Their Prospective Biotechnological Applications: An Overview. Biol. Trace Elem. Res. 2021, 199, 344-370. [CrossRef] 
241. El-Belely, E.F.; Farag, M.M.S.; Said, H.A.; Amin, A.S.; Azab, E.; Gobouri, A.A.; Fouda, A. Green Synthesis of Zinc Oxide Nanoparticles (ZnO-NPs) Using Arthrospira platensis (Class: Cyanophyceae) and Evaluation of their Biomedical Activities. Nanomaterials 2021, 11, 95. [CrossRef]

242. Rahman, S.; Rahman, L.; Khalil, A.T.; Ali, N.; Zia, D.; Ali, M.; Shinwari, Z.K. Endophyte-mediated synthesis of silver nanoparticles and their biological applications. Appl. Microbiol. Biotechnol. 2019, 103, 2551-2569. [CrossRef]

243. Monowar, T.; Rahman, M.S.; Bhore, S.J.; Raju, G.; Sathasivam, K.V. Silver Nanoparticles Synthesized by Using the Endophytic Bacterium Pantoea ananatis are Promising Antimicrobial Agents against Multidrug Resistant Bacteria. Molecules 2018, $23,3220$. [CrossRef] [PubMed]

244. Fouda, A.; Hassan, S.E.D.; Abdo, A.M.; El-Gamal, M.S. Antimicrobial, Antioxidant and Larvicidal Activities of Spherical Silver Nanoparticles Synthesized by Endophytic Streptomyces spp. Biol. Trace Elem. Res. 2020, 195, 707-724. [CrossRef]

245. Hassan, S.E.L.D.; Salem, S.S.; Fouda, A.; Awad, M.A.; El-Gamal, M.S.; Abdo, A.M. New approach for antimicrobial activity and bio-control of various pathogens by biosynthesized copper nanoparticles using endophytic actinomycetes. J. Radiat. Res. Appl. Sci. 2018, 11, 262-270. [CrossRef]

246. Hassan, S.E.-D.; Fouda, A.; Radwan, A.A.; Salem, S.S.; Barghoth, M.G.; Awad, M.A.; Abdo, A.M.; El-Gamal, M.S. Endophytic actinomycetes Streptomyces spp mediated biosynthesis of copper oxide nanoparticles as a promising tool for biotechnological applications. JBIC J. Biol. Inorg. Chem. 2019, 24, 377-393. [CrossRef]

247. Baker, S.; Satish, S. Biosynthesis of gold nanoparticles by Pseudomonas veronii AS41G inhabiting Annona squamosa L. Spectrochim. Acta Part A: Mol. Biomol. Spectrosc. 2015, 150, 691-695. [CrossRef]

248. El-Moslamy, S.H. Bioprocessing strategies for cost-effective large-scale biogenic synthesis of nano-MgO from endophytic Streptomyces coelicolor strain E72 as an anti-multidrug-resistant pathogens agent. Sci. Rep. 2018, 8, 3820. [CrossRef] [PubMed]

249. Yousef, N.; Mawad, A.; Abeed, A. Enhancement the Cellulase Activity Induced by Endophytic Bacteria Using Calcium Nanoparticles. Curr. Microbiol. 2019, 76, 346-354. [CrossRef]

250. Rajabairavi, N.; Raju, C.S.; Karthikeyan, C.; Varutharaju, K.; Nethaji, S.; Hameed, A.S.H.; Shajahan, A. Biosynthesis of Novel Zinc Oxide Nanoparticles (ZnO NPs) Using Endophytic Bacteria Sphingobacterium thalpophilum. In Proceedings of the Recent Trends in Materials Science and Applications; Springer: Cham, Switzerland, 2017; pp. 245-254.

251. Ibrahim, E.; Fouad, H.; Zhang, M.; Zhang, Y.; Qiu, W.; Yan, C.; Li, B.; Mo, J.; Chen, J. Biosynthesis of silver nanoparticles using endophytic bacteria and their role in inhibition of rice pathogenic bacteria and plant growth promotion. RSC Adv. 2019, 9, 29293-29299. [CrossRef]

252. Eid, A.M.; Fouda, A.; Niedbała, G.; Hassan, S.E.D.; Salem, S.S.; Abdo, A.M.; Hetta, H.F.; Shaheen, T.I. Endophytic Streptomyces laurentii mediated green synthesis of Ag-NPs with antibacterial and anticancer properties for developing functional textile fabric properties. Antibiotics 2020, 9, 641. [CrossRef]

253. Salem, S.S.; El-Belely, E.F.; Niedbała, G.; Alnoman, M.M.; Hassan, S.E.D.; Eid, A.M.; Shaheen, T.I.; Elkelish, A.; Fouda, A. Bactericidal and in-vitro cytotoxic efficacy of silver nanoparticles (Ag-NPs) fabricated by endophytic actinomycetes and their use as coating for the textile fabrics. Nanomaterials 2020, 10, 82. [CrossRef] [PubMed]

254. Ibrahim, E.; Zhang, M.; Zhang, Y.; Hossain, A.; Qiu, W.; Chen, Y.; Wang, Y.; Wu, W.; Sun, G.; Li, B. Green-Synthesization of Silver Nanoparticles Using Endophytic Bacteria Isolated from Garlic and Its Antifungal Activity against Wheat Fusarium Head Blight Pathogen Fusarium graminearum. Nanomaterials 2020, 10, 219. [CrossRef] [PubMed] 